\title{
Anomalous Carbonate Precipitates: Is the Precambrian the Key to the Permian?
}

\author{
JOHN P. GROTZINGER \\ Department of Earth, Atmospheric and Planetary Sciences, Massachusetts Institute of Technology, \\ Cambridge, MA 02139
}

ANDREW H. KNOLL

Botanical Museum, Harvard University, Cambridge, MA 02138

PALAIOS, 1995, V. 10, p. 578-596

Late Permian reefs of the Capitan complex, west Texas; the Magnesian Limestone, England; Chuenmuping reef, south China; and elsewhere contain anomalously large volumes of aragonite and calcite marine cements and seafloor crusts, as well as abundant microbial precipitates. These components strongly influenced reef growth and may have been responsible for the construction of rigid, open reefal frames in which bryozoans and sponges became encrusted and structurally reinforced. In some cases, such as the upper biostrome of the Magnesian Limestone, precipitated microbialites and inorganic crusts were the primary constituents of the reef core. These microbial and inorganic reefs do not have modern marine counterparts; on the contrary, their textures and genesis are best understood through comparison with the older rock record, particularly that of the early Precambrian.

Early Precambrian reefal facies are interpreted to have formed in a stratified ocean with anoxic deep waters enriched in carbonate alkalinity. Upwelling mixed deep and surface waters, resulting in massive seafloor precipitation of aragonite and calcite. During Mesoproterozoic and early Neoproterozoic time, the ocean became more fully oxidized, and seafloor carbonate precipitation was significantly reduced. However, during the late Neoproterozoic, sizeable volumes of deep ocean water once again became anoxic for protracted intervals; the distinctive "cap carbonates" found above Neoproterozoic tillites attest to renewed upwelling of anoxic bottom water enriched in carbonate alkalinity and ${ }^{12} \mathrm{C}$. Anomalous late Permian seafloor precipitates are interpreted as the product, at least in part, of similar processes. Massive carbonate precipitation was favored by: 1) reduced shelf space for carbonate precipitation, 2) increased flux of $\mathrm{Ca}$ to the oceans during increased continental erosion, 3) deep basinal anoxia that generated upwelling waters with elevated alkalinities, and 4) further evolution of ocean water in the restricted Delaware, Zechstein, and other basins. Temporal coincidence of these processes resulted in surface seawater that was greatly supersaturated by Phanerozoic standards and whose only precedents occurred in Precambrian oceans.

\section{INTRODUCTION}

The anomalously large quantities of marine cement and related facies in certain late Permian carbonate successions present an enduring enigma in Earth history. Epitomized by the Guadalupian reef complex of west Texas, these rocks are among the world's most intensively studied but least understood carbonate buildups. Over the past 20 years it has become increasingly clear that the Permian reef complex of west Texas is atypical of Phanerozoic reefs for reasons that continue to be debated (e.g., Wood et al., 1994). Classic models for barrier reef accretion are difficult to apply; even the water depth in which the reef grew eludes consensus. More troubling still, there is no agreement on the principal mechanism of accretion for at least the younger part of the reef; did it accumulate in classical biohermal fashion through the growth of skeletonized macrobenthos, or was accretion strongly influenced, or perhaps even dominated by the growth of a framework formed of seafloor-encrusting marine cements and/or microbialites?

Our understanding of modern processes strongly influences reconstructions of past events. In the context of reef growth, "the present is the key to the past" means that the upward propagation of an attached skeletal benthos provides the paradigm for interpretation. Reefs whose framework is supplemented or even constructed mostly by 
marine cement growing directly on the sea floor are unknown in the modern oceans and, thus, unsuspected in most Phanerozoic build-ups. However, during the past decade, research on Precambrian carbonates has produced evidence that during the first half of recorded Earth history, reef complexes existed that were dominated by massive marine cements and whose only possible biologic components were microorganisms (Grotzinger, 1988, 1989, 1990). In this light, it is intriguing to consider the possibility that the Precambrian record of carbonate sedimentation may offer insight into conspicuous but (according to the standard reef paradigm) anomalous facies of the Permian.

This approach is justified, and perhaps even required, because the Earth operates as a complex system of diverse interactions among processes whose characteristic time scales range from seconds to billions of years. The kinetics of calcium carbonate precipitation may best be understood by studies of the modern ocean supplemented by laboratory experiments. However, for processes that evolve over longer time scales, the modern Earth may be a transient that is not representative of the average state of the system. This is the lesson of meteorite impacts (Alvarez, 1986), and it applies as well to Earth-bound processes whose occurrence is tied to tectonic, oceanographic, and/or biological processes not currently observable. To cite a key example, the history of the oceans and atmosphere is, as far as we know, one of the progressive oxidation of anoxic Early Archean environments (e.g., Cloud, 1968). Today, the oceans are fully oxygenated, with the exception of local sites of upwelling or stagnation. It is thought that during the Phanerozoic, the current state of the system alternated with episodes of ocean stratification during which only surface waters were fully oxidizing (e.g., Degens and Stoffers, 1976; Holser, 1984). Just as the modern ocean provides a suitable model for past states of a fully-oxidized ocean, the early Precambrian may be regarded as an endmember analog for the episodes of ocean anoxia.

In this paper, we investigate the possibility that certain Phanerozoic carbonate facies, perhaps best expressed by the late Permian of west Texas and England, have relevant analogs of Precambrian age. The Precambrian perspective allows us to articulate a hypothesis linking the local accumulation of voluminous seafloor crusts and precipitated microbialites to the dynamics of an adjacent stratified marine basin.

\section{LATE PERMIAN REEF FACIES \\ Capitan Reef Complex, West Texas}

The Guadalupian Capitan limestone of west Texas and New Mexico has been studied extensively since the late 1920's. Almost from the time that the Capitan was first proposed as a fossil barrier reef (Lloyd, 1929), doubt was cast on its biogenicity. For example, Lang (1937) argued that reef development was likely supplemented substantially by inorganically-mediated calcium carbonate precipitation. Lang also was the first to suggest that the Cap- itan facies was not a reef but a marginal mound built of loose bioclastic sediment.

The organic barrier reef hypothesis was perpetuated in subsequent studies by King (1942), Newell et al. (1953), Newell (1955), and Hayes (1964), although King (1948) later recanted, noting that 1 ) fossils were generally scarce within the reef, and 2) those that are present would more likely have produced a shallow sandy shoal than a framework reef. King further argued that shoal conditions would have favored direct precipitation of calcium carbonate on the sea floor without the aid of organisms.

A third generation of studies, beginning in the mid 1960's and ending in the late 1970's, reinvigorated the debate and further eroded support for the classic barrier reef model. Baars (1964) and Achauer (1969) both questioned the reef interpretation, arguing instead for an organic bank. Dunham $(1969,1972)$ pointed out that the the build-up likely was not a barrier built to sea level but rather a submerged feature that lay seaward of a shoal complex characterized by vadose pisolite. Babcock (1977) and Yurewicz (1977) provided evidence for several biozones in the reef, based on the distribution of phylloid algae, sponges, Tubiphytes, and other possible framebuilders. More recently, Kirkland et al (1993) have argued that the youngest part of the reef did build to sea level and that a narrow lagoon existed between the reef and the pisolite shoal envisioned by Dunham (1969).

\section{Marine Cements and Seafloor Crusts}

By the early 1970's it was recognized that the Capitan limestone, particularly its youngest part, contains vast quantities of marine cement that locally form $50 \%$ to $80 \%$ of the reef (Schmidt and Klement, 1971; Schmidt, 1977). This was emphasized in SEPM Publication 77-16, in which a multiauthored position paper (Cys et al., 1977) concludes that "the Capitan is an inorganic-framework reef with a significant organic-framework component." The possibility that the reef may have been constructed principally of seafloor-encrusting ${ }^{1}$ marine aragonite and calcite was made easier to accept by detailed petrographic studies that demonstrated an intimate association between cements and other primary marine components (Mazzullo and Cys, 1977;

\footnotetext{
${ }^{1}$ In this paper we use the term "seafloor encrustation" to refer to originally aragonite and calcite marine precipitates which grew directly on the sea floor, as distinct from true cements which bind sediment particles and line voids. In the case of the Guadalupian reef, the true volume of primary sea-floor precipitates may be systematically underestimated because primary growth surfaces may have been very irregular owing to the presence of rod- and sheetshaped metazoans and metaphtyes. Thus sea-floor precipitates generally would appear to grow in many directions (including downwards), rather than preferentially upwards, giving the false impression of growth in voids. Although the point at which the highly invaginated sea floor becomes isolated to form a void maybe difficult to ascertain in the field, for the purpose of this paper we consider all those surfaces which are in contact with well-circulated seawater to constitute the sea floor.
} 
Schmidt, 1977; Yurewicz, 1977) and by the discovery of fibrous cements precipitated from the modern oceans (Land and Goreau, 1970; Ginsburg and James, 1973). Prior to this, fibrous carbonates in the Capitan reef had been interpreted as post-depositional recrystallization textures (Newell et al., 1953; Tyrell, 1964; Cronoble, 1974) or as subaerial cements (Dunham, 1969). Recent studies of the Capitan reef have continued to emphasize the contribution of marine cement in the construction of the reefal frame, particularly its upper part (Babcock and Yurewicz, 1989; Mruk, 1989).

\section{Archaeolithoporella}

Application of the modern reef paradigm to the upper Capitan limestone requires that one identify the framebuilding organisms responsible for bioherm accretion. The general consensus is that two categories of benthos could have provided the necessary framework: 1) sponges and other organisms that lacked a calcareous skeleton but were lithified on the sea floor by marine cements, and 2) organisms with solid calcareous skeletons, including bryozoans, calcareous algae, Tubiphytes, and encrusting foraminifera and corals. Forams and corals are so sparsely distributed that they could not have formed the reef framework (Cys et al., 1977) and, as noted above, Wood et al. (1994) have interpreted the dominant sponges as cryptobionts. (We note that Wood et al.'s interpretation is controversial and that earlier interpretations (Babcock, 1977; Yurewicz, 1977) emphasized the erect, framebuilding nature of the sponges.) The remaining candidates are principally calcareous algae, along with locally dense thickets of bryozoans bound together by marine cement (Wood et al., 1994). The volumetrically most important structures identified as algae, however, are not standard issue calcareous reds and greens; all are problematic.

Archaeolithoporella is commonly regarded as an essential component of the Capitan reef framework. Morphologically, it consists of alternating laminae of dark, organicrich micrite and light, clear microspar that form crusts on the order of a few tens of microns to several millimeters thick (See figures 20 and 23 of Cys et al., 1977; figures 1, 2, 3, and 12 of Mazzullo and Cys, 1977; and figure 10 of Babcock, 1977). Dark and light laminae are roughly equal in thickness, and the crusts coat antecedent topography isopachously. Functionally, Archaeolithoporella is thought to have acted as an encruster, and its overgrowing laminations bind various biotic elements, including sponges, bryozoans, and Tubiphytes (Babcock, 1977). This structure is also found in intimate association with thick, encrusting masses of fibrous marine cement, and it occurs in neptunian dikes that transect the reef (e.g., Mazzullo and Cys, 1977).

Despite its presence in neptunian dikes and the absence of evidence for tissue differentiation, cross partitions, or other features consistent with the presence of cells (Babcock, 1977; Wray, 1977), Archaeolithoporella is commonly interpreted as a red alga. Mazullo and Cys (1977) supported this view on the basis of: 1) the uniform thickness of laminae, 2) a lack of recognizable particulate debris that might identify these structures as stromatolites, 3) the uniform thickness of crusts regardless of orientation (top, bottom, or sides of cavities or grains), and 4) the clearness of crystals. In addition, Archaeolithoporella also forms mounds less than 1 meter in diameter, which Mazullo and Cys (1977) considered to be inconsistent with a microbial or inorganic origin. "The fact that Archaeolithoporella had the apparent capability to form discrete, current-resistant heads is strong, although indirect, evidence of its organic nature. I know of no inorganic agent or process that could form these laminated heads" (Cys et al., 1977). On the other hand, Newell et al (1953) considered Archaeolithoporella to be stromatolitic, and Dunham (1969) and Schmidt (1977) interpreted the crusts as laminated micrite cements.

Our experience in working with Precambrian microbialites and related sediments suggests that all of the criteria listed Mazullo and Cys (1977) in support of a higher algal interpretation of Archaeolithoporella are equally consistent with a microbial or entirely inorganic origin. It has been emphasized recently that microbialites formed by precipitation rather than trapping and binding are widely distributed in Precambrian rocks, particularly in those older than about $1000 \mathrm{Ma}$ (Grotzinger and Read, 1983; Grotzinger, 1986a, 1989, 1990, 1994; Knoll et al., 1993; Sami and James, in press; Sumner and Grotzinger, in review; Kah and Knoll, in press). These precipitated microbialites all have the following attributes: fine lamination, extremely even lamination, and uniform lamina thickness regardless of depositional orientation (Fig. 1). That is, they exhibit the precise suite of features marshalled by Mazullo and Cys (1977) in support of their interpretation of $\mathrm{Ar}^{-}$ chaeolithoporella as a rhodophyte. In Precambrian microbialites, these features all seem to relate to deposition in environments where the flux of clastic carbonate and/ or other sediment was low relative to the rate of seafloor precipitation.

Given its attributes, Archaeolithoporella is most parsimoniously interpreted as a precipitated microbialite, supporting the original stromatolitic interpretation of Newell et al. (1953). The alternation in Archaeolithoporella of fibrous light and micritic dark laminae is indeed atypical (Mazzullo and Cys, 1977) of previously described, purely inorganic marine cements. A possible interpretation of Archaeolithoporella's distinctive fabric derives from observations of Recent carbonate precipitation in Satonda Crater Lake, Indonesia, used by Kazmierczak and Kempe (1992) to explain the problematic Paleozoic fossil Wetheredella. In their model, microbial mats growing in a sealinked lake highly oversaturated with respect to calcium carbonate become calcified during seasonal changes in the supersaturation of lake surface waters. Initially, a micritic $\mathrm{Mg}$-calcite crust forms on the mat surface. Subsequently, the mat below the crust undergoes bacterial decomposition, facilitating the precipitation of fibrous aragonite. The resulting texture features dark, micritic laminae of submillimeter thickness alternating with clear laminae that would become sparry following neomorphic inversion of 

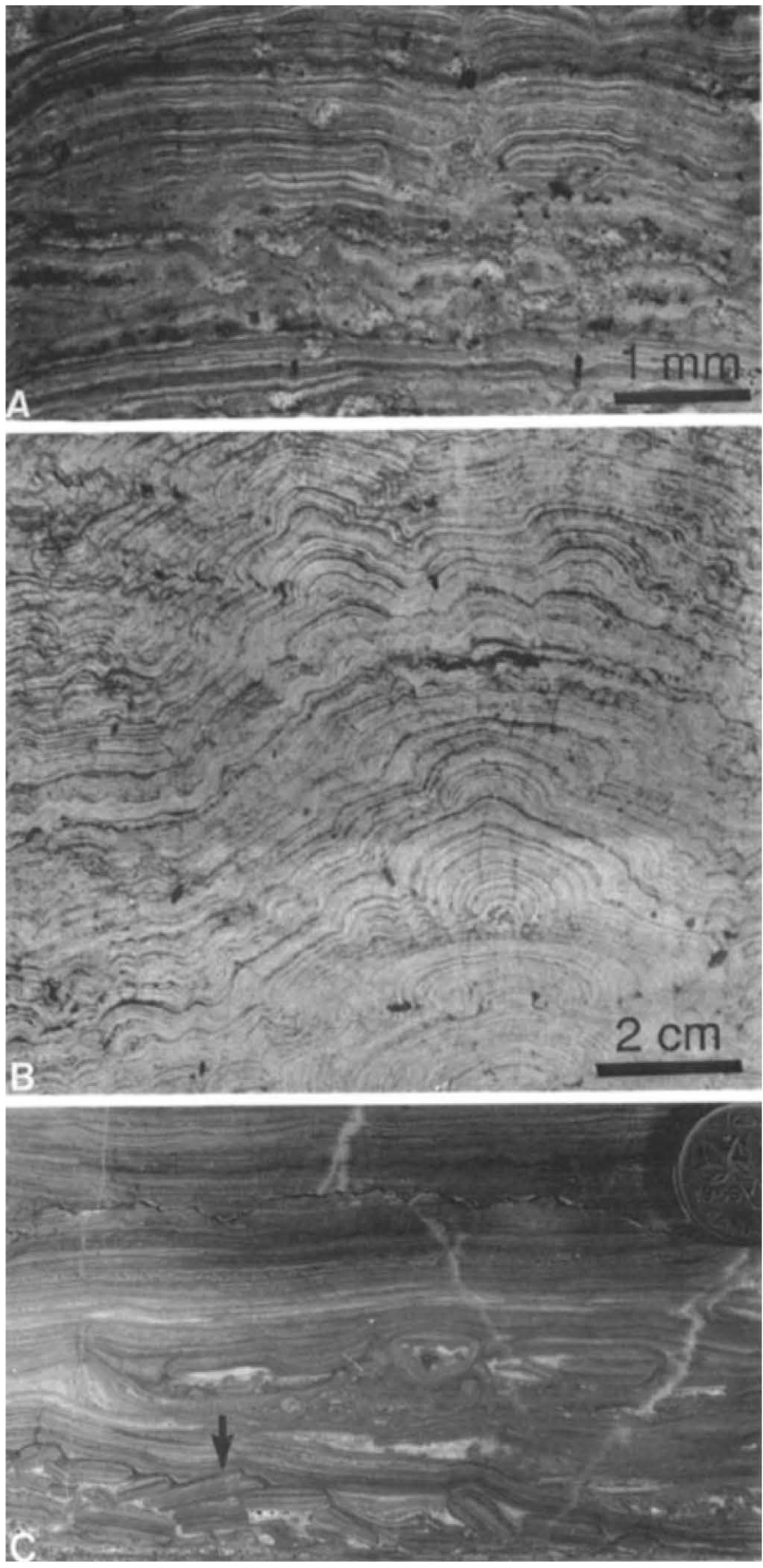

FIGURE 1-Precipitated Archean and Proterozoic stromatolites. (a) Photomicrograph of sub-millimeter scale lamination in precipitated stratiform stromatolites, Mesoproterozoic Kotuikan Formation, northwest Siberia. Precursor carbonate mineral (probably calcite) has been replaced by early diagenetic chert. Note the even, continuous lamination. (b) Millimeter to sub-millimeter scale lamination in irregular, stratiform to domal stromatolites, late Archean Malmani Subgroup, South Africa. Lamination is characterized by consistent thickness and remarkable lateral continuity despite significant depositional surface roughness. Outcrop photograph courtesy of Dawn Summer. (c) Submillimeter to millimeter scale lamination in precipitated stratiform stromatolites, Paleoproterozoic Wildbread Formation, northwest Canada. the aragonite. The only significant difference between the textures of Archaeolithoporella and the calcified microbial structures discussed by Kazmierczak and Kempe (1992) is the irregular thickness of the aragonite layer in the latter. However, this results from the initially pustular surface morphology created by mat-building coccoidal cyanobacteria. We suggest that in mats constructed by filamentous cyanobacteria, the laminated fabric would be far more even, providing a good analogue for Archaeolithoporella. Indeed, relatively even laminae of alternating clear spar and dark micrite are common in precipitated stromatolites formed in Phanerozoic lakes (papers in Bertrand-Sarfati and Monty, 1994).

\section{Collenella}

According to Babcock (1977), "Collenella is the principal framebuilding organism in the upper Capitan, ... a problematic form that superficially resembles an algal stromatolite." Morphologically, Collenella structures are unlinked, digitate columnar growths consisting of stacked layers of bladed crystals and other "vertical elements" oriented perpendicular to the hemispherical growth surface (see Babcock, 1977, figures 7, 31, 32, and 33; Toomey and Cys, 1977, figure 4a). "Although Collenella superficially resembles algal stromatolites," continued Babcock (1977), "its internal structure is wholly unlike that of stromatolites ... an algal stromatolite is an organo-sedimentary structure consisting of grains of sediment trapped and bound in a characteristic laminated form. Not only did Collenella not trap and bind sediment, but its rigid skeletal structure excluded sediment from the space that it occupied. Other factors that are incompatible with an algal stromatolite interpretation for Collenella include the observations that no filaments of any kind were observed, that Collenella grew initially as an encrustation on firm substrates and formed a rigid framework, and that Collenella is found in association with a diverse and abundant solid-substrate benthic marine fauna and flora."

As noted above, stromatolites formed by direct precipitation on the sea floor are a conspicuous feature of Archean and Proterozoic carbonates. Isopachous sparitic, fibrous and micritic layering, generally devoid of clastic carbonate, is the characteristic microstructure. These structures were fully lithified as they accreted and, therefore, formed rigid structures that encrusted firm substrates. The absence of filaments is not surprising; preserved filaments are rare or absent from Precambrian precipitated stromatolites. Thus, Babcock's conclusion that Collenella must be a calcified alga because it can't be a stromatolite is unfounded.

Collenella structures in the Upper Capitan reef are strikingly similar to a class of Precambrian "microdigitate" stromatolites that are widely distributed and abundant in

$\leftarrow$

Laminae are extremely even and laterally continuous as shown by the lamina (at arrow) which encrusts intraciasts. Polished slab. 

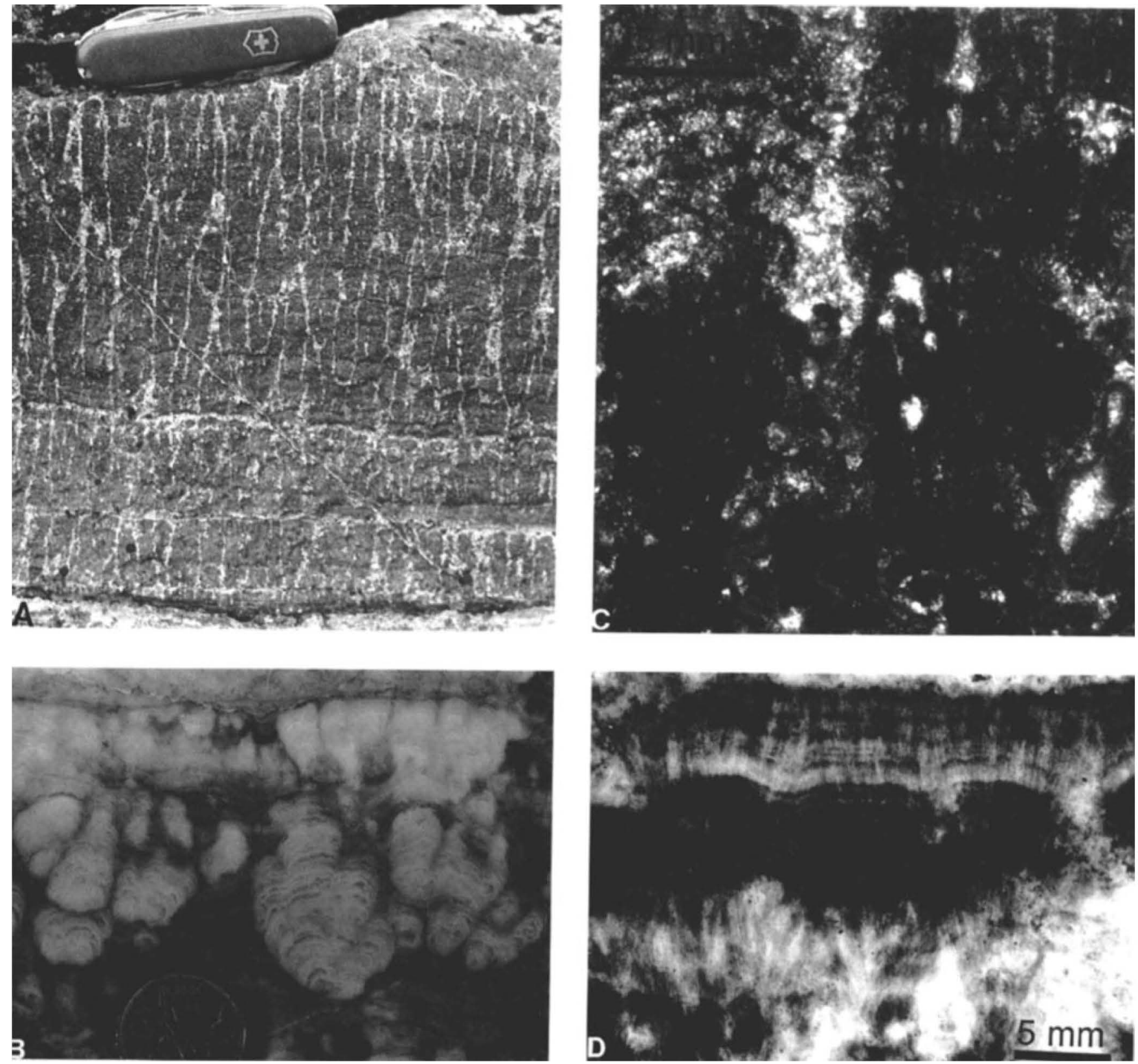

FIGURE 2-Precipitated microdigitate stromatolites. (a) Branching, columnar microdigitate stromatolites, Paleoproterozoic Rocknest Formation, northwest Canada. These stromatolites are characteristic of inner-shelf peritidal facies. (b) Branching, columnar microdigitate stromatolites, Paleoproterozoic Rocknest Formation, northwest Canada. These stromatolites tend to occur in shoal complex peritidal facies. (c) Photomicrograph of two microdigitate stromatolites, Paleoproterozoic Rocknest Formation, northwest Canada. Note palimpsest radial-fibrous texture which is consistent with replacement of former acicular minerals. Preserved carbonate textures, now dolomite, suggest neomorphic replacement of former aragonite (Grotzinger and Read, 1983). Each radial fibrous fan corresponds to a single stromatolite column. (d) Photomicrograph of microdigitate stromatolites, Mesoproterozoic Kotuikan Formation, northwest Siberia. Excellent preservation in early chert (which predated carbonate mineral inversion) shows radial fibrous textures consistent with the former presence of acicular mineral splays, probably aragonite.

Paleoproterozoic (2.5 to $1.6 \mathrm{Ga}$ ) carbonates; present, but only regionally abundant in the Mesoproterozoic (1.6 to $1.0 \mathrm{Ga}$ ); and rare thereafter (Grey and Thorne, 1985; Grotzinger, 1989; 1990). They are typically less than $1 \mathrm{~cm}$ wide, have well-defined fine lamination, exhibit active branch- ing, and lack wall structure and lateral linkage (Fig. 2a, b). In thin section, their microstructure is dominated by neomorphic spar textures consistent with replacement of either aragonite (Fig. 2c; crystals subequant and optic axes randomly oriented) or calcite (crystals preferentially elon- 
gated normal to layering, optic axes parallel to elongation). Micrite is rare, except where stromatolite growth is terminated. Where preserved in chert that predated neomorphic inversion, the primary fibrous mineral texture is clearly visible (Fig. 2d).

Field studies first suggested that microdigitate stromatolites formed by precipitation (Hoffman, 1975), and subsequent petrographic work corroborates this conclusion (Grotzinger and Read, 1983; Grotzinger, 1986a; Hofmann and Jackson, 1988; Knoll et al., 1993a). We emphasize that in Precambrian microdigitate stromatolites, precipitation may not have been induced by active microbial mats. To the extent that biology was involved at all, it was likely the geochemical effects of heterotrophic bacteria that promoted precipitation (Canfield and Raiswell, 1991; Chafetz and Buczynski, 1992). Petrographic studies of microdigitate stromatolites preserved in very early diagenetic chert support models of growth entirely by the precipitation of fibrous marine aragonite and calcite, with little evidence for the involvement of microbial mats (Fig. 2c, d; Hofmann and Jackson, 1988; Knoll et al., 1993a; Sergeev et al., 1995).

We suggest that the upper Capitan structures classified as Collenella and regarded as calcified algae are either precipitated stromatolites of microbial origin or largely inorganic structures comparable to those found in Precambrian carbonates and Cenozoic tufas. In either interpretation, Collenella is a precipitated structure and not a calcareous alga. Like Archaeolithoporella, Collenella underscores the potentially tremendous volume of non-metabolically precipitated carbonate in the Upper Capitan reef.

\section{THE MAGNESIAN LIMESTONE REEF AND OTHER ANOMALOUS LATE PERMIAN CARBONATES}

The precipitated carbonates of the upper Capitan reef would be remarkable enough if unique; they become all the more intriguing when seen as part of a wider feature of late Permian platform margins. The upper Permian Middle Magnesian Limestone (now known as the Ford Formation; Smith, 1994) of County Durham, northern England, also has been regarded as containing one of the classic Phanerozoic reefs. Its fauna was described 100 years before the discovery of the west Texas reefs (Sedgwick, 1829). Most recently, the Middle Magnesian reef has been studied by Smith $(1981,1994,1995)$ and Hollingworth and Tucker (1987). Smith (1981) confirmed earlier suggestions that the reef has a basal coquina which gives way to a welldeveloped bryozoan-dominated reef core. The reef core grades upwards into a reef-flat facies that becomes progressively more dominated by algal or inorganic encrustations, culminating in a stromatolitic biostrome.

\section{Marine Cements and Seafloor Crusts}

On the whole, the reef is poorly preserved due to pervasive dolomite replacement, but it seems to share much in common with the Capitan reef of west Texas-a lower and middle reef dominated by organic components that passes upward into a cement-dominated and possibly mostly microbial component. Smith (1981) allowed that extensive recrystallization may have obscured massive marine cementation but stated that "even if 90 percent of the reef were shown to have been formed by inorganically precipitated carbonate, it would still be reasonable to regard it as an organic structure if without the 10 percent of organisms the reef would not have been formed." In this statement it is important to note the strong, but unsubstantiated, bias against the potentially essential role played by inorganic or microbial processes. Subsequent discovery of limestones in the basal part of the reef (Tucker and Hollingworth, 1986; Hollingworth and Tucker, 1987) have resulted in the demonstration that "seafloor cement precipitation was a major factor in the construction of a wave resistant structure" (Hollingworth and Tucker, 1987). The cements are volumetrically important in the preserved limestones, and Hollingworth and Tucker estimate that as much as $80 \%$ of the bryozoan framework was filled with aragonitic marine cement. Inspection of equivalent dolomitized facies shows relics of aragonitic textures that are similarly consistent with widespread marine cementation.

Until the mid-1980's the significance of marine cementation was not confirmed and, thus, not fully appreciated. Because of the extensive dolomitization it is unclear if the marine precipitates recorded by Tucker and Hollingworth (1986), although volumetrically important, were restricted to the pores of a bryozoan frame, or whether the precipitates actually formed part of the frame itself. In either case, what is clear is that the build-up contained a vast quantity of marine calcium carbonate precipitates that must be accounted for in any interpretation of reef genesis.

\section{Stromatolites, “Laminar Encrustations," and Problematica}

Smith (1981) observed that middle portions of the Magnesian Limestone reef are characterized by a progressive increase in the proportion of algal rocks and "laminar organic or inorganic encrustations" at the expense of the bryozoa that dominated early stages of reef growth. Stromatolites and other "laminar rocks" are noted to become dominant in the latest phases of reef growth, beneath the more-or-less tabular biostrome, 30 meters thick, of finelylaminated subtidal stromatolites. With regard to the scattered, small columnar growth forms below the capping stromatolite biostrome, Smith (1981) notes that "In morphology they resemble colleniform algal stromatolites, but subtle differences in proportions from those of most stromatolites of the reef-flat suggest closer affinity with a skeletal organism similar to the problematical Collenella of comparable parts of the Capitan limestone of New Mexico." On the basis of Smith's (1981) descriptions and illustrations, we conclude that the Magnesian Limestone reef Collenella, like those of the Capitan Limestone, are microbial or inorganic precipitate structures.

Smith (1981) regarded the biostrome of the Magnesian 

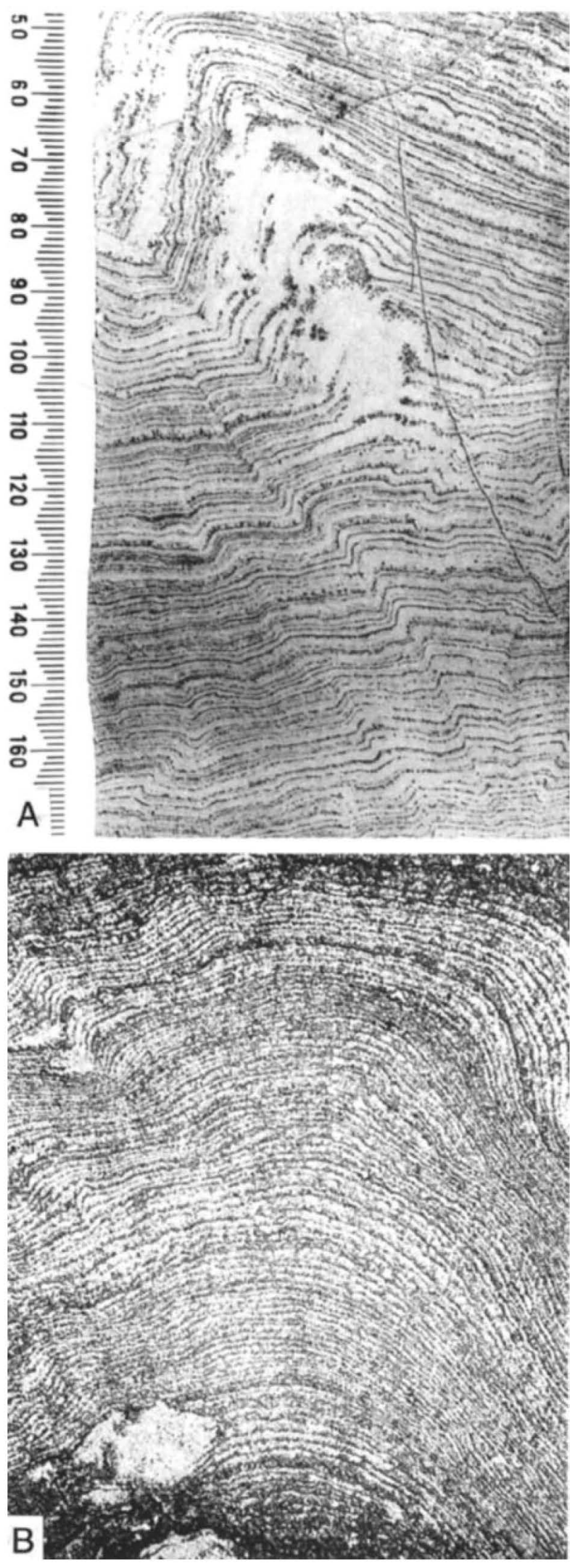

Limestone as stromatolitic, and we concur. Given descriptions and illustrations of the stromatolites, we would add that they appear to be predominantly of precipitated origin (compare Fig. 1b with Fig. 3a; also see figure 27 of Smith, 1981). Characteristically, these stromatolites have fine, uniform laminations that show extensive lateral continuity; in consequence, small perturbations along individual laminae are often propagated upward for many younger laminae (Fig. 3), as in the "Crinkly Bed" of Smith (1995).

The framework of the Magnesian Limestone reef contains a significant component of problematic structures described as laminar, nodose, concentric, and columnar "encrustations" (Smith, 1981). Smith considered that "in many places, indeed, laminar encrustations make up 80 to 90 percent of the rock." He drew comparisons between some of the encrusting laminae and the Archaeolithoporella described from the Capitan reef, noting that the interpretation of Archaeolithoporella as a red alga applied equally well to the Magnesian Limestone reef. Like its Texan counterpart, Archaeolithoporella in the Magnesian Limestones reef is more convincingly interpreted in terms of microbial mat calcification under marine conditions of elevated calcium carbonate supersaturation.

\section{Other Precipitate-Rich Late Permian Reefs}

Not all Late Permian build-ups are dominated by microbialites and seafloor encrustations (Flügel and Reinhardt, 1989); nonetheless, the wide distribution of precipiated carbonates shows them to be a global phenomenon. Encrusted bryozoan frameworks characterize reef mounds along the margin of an anoxic deep basin in East Greenland (Hurst et al., 1989; these reefs originally may have belonged to the other side of the Zechstein basin prior to opening of the Atlantic ocean). Reef facies dominated by Archaeolithoporella and seafloor encrusting precipitates also occur in Late Permian reefs of Greece (Flügel and Reinhardt, 1989), Slovenia (Flügel et al., 1984), and the Caucasus (Pisera and Zawidzka, 1981). Peryt (1986) studied the Zechstein buildups of Thuringa and concluded that these, too, are algal-cement reefs. Furthermore, he noted the textural similarity between Archaeolithoporella and the problematic structure Stromaria, which was an essential contributer to reef growth, and suggested a common origin.

Curious, travertine-like microbial carbonates have re-

$\leftarrow$

FIGURE 3-Stromatolites of the Magnesian Limestone biostrome. (a) Polished slab of core showing fine, even, laterally continuous lamination characteristic of Precambrian precipitated stromatolites. Compare with Figure $1 \mathrm{~b}$. Scale in millimeters. Photograph courtesy of D. Smith and reproduced with permission of SEPM. (b) Thin section photomicrograph of stromatolitic lamination similar to that shown in 3a. Sample is from outcrop at Hawthorne quarry. Field of view is approximately $4 \times 7 \mathrm{~cm}$. Photograph courtesy of $M$. Tucker. 


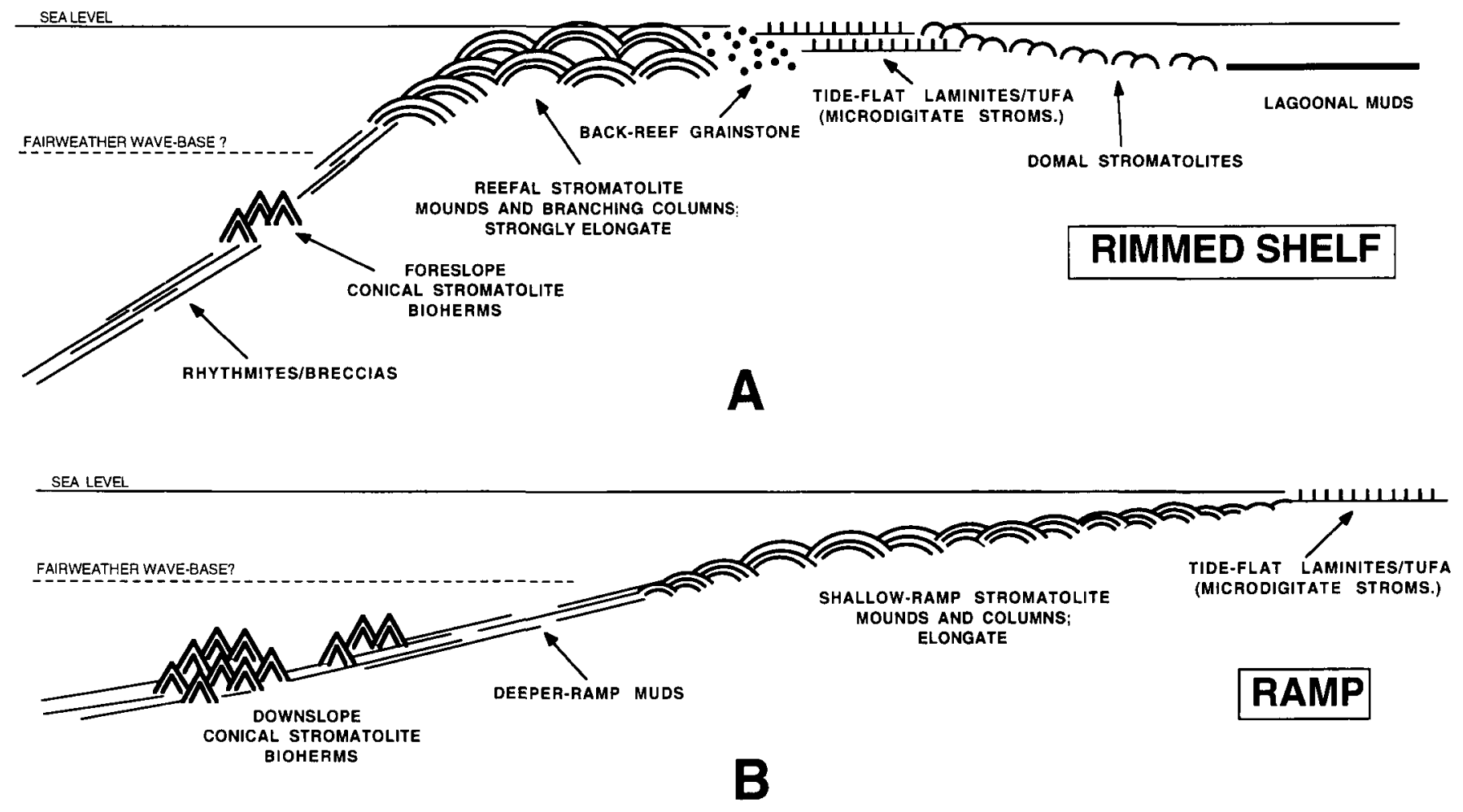

FIGURE 4-Stromatolitic reefs and buildups developed on Precambrian carbonate platforms. (a) Facies distribution on rimmed shelf. (b) Facies distribution on ramp. Note: Microdigitate stromatolites and other precipitated crusts are ubiquitous in Paleoproterozoic and older tidal-flat facies, variably developed in Mesoproterozoic carbonates, and rare or absent in Neoproterozoic rocks. After Grotzinger (1989).

cently been shown to be an important component of the Chuenmuping reef, Sichuan Basin, south China (Guo and Riding, 1992). Here, the dominant stage of reef growth is characterized by deposition of $60 \%$ micritic carbonates that are thought to be largely of microbial origin. Guo and Riding (1992) provided evidence for participation of microbial carbonates in (1) infilling reefal cavities, (2) encrusting framework organisms, and (3) encrusting the sea floor where framework organisms were absent.

The microbial carbonates consist largely of micrites with irregular, clotted, and scalloped-laminated fabrics. Guo and Riding (1992) suggest that the carbonates were formed in a manner analogous to Cenozoic travertines formed in hot springs. In this environment cyanobacteria and bacteria play an essential role in regulating carbonate precipitation in the presence of highly oversaturated discharging water (Chafetz and Buczynski, 1992; Chafetz and Folk, 1984). Locally Archaeolithoporella is an important component of the Chuenmuping reef (Guo and Riding, 1992).

In summary, there is substantial evidence that, as in the upper Capitan reef complex, construction of Magnesian Limestone and other Late Permian reefal frames involved a major, perhaps essential, component of growth by seafloor carbonate precipitation in the form of aragonite and calcite crusts and cements, and precipitated sparitic and micritic microbialites.

\section{PRECAMBRIAN REEF FACIES}

Late Permian microbialite/cement reefs may seem anomalous to geologists studying modern reefs, but to a time traveler transported from the early Precambrian, the late Permian deposits would be just about the only Phanerozoic reefs that would appear normal. Therefore, it is pertinent to ask whether processes inferred to have been important in Precambrian reef growth may help to explain the upper Capitan limestone and other late Permian buildups.

Archean and Proterozoic successions contain patch reefs, barrier reefs, pinnacle reefs, and foreslope reefs-all built by microbial mat communities and seafloor cements in varying proportions (Grotzinger, 1988, 1989; papers in Geldsetzer et al., 1988). Significant variations in reef geometry, growth forms of constituent stromatolites, and microfabric development attest to a relatively high level of interaction among physical, chemical and biologic controls (Fig. 4).

Precambrian reefs show clear evidence for growth above surrounding sediments in both shallow and deeper water settings (Grotzinger, 1988, 1989; papers in Geldsetzer et al., 1988). Additionally, some reefs evolved by growth from initially deep through progressively shallower water waveagitated settings, followed by continued growth within the 

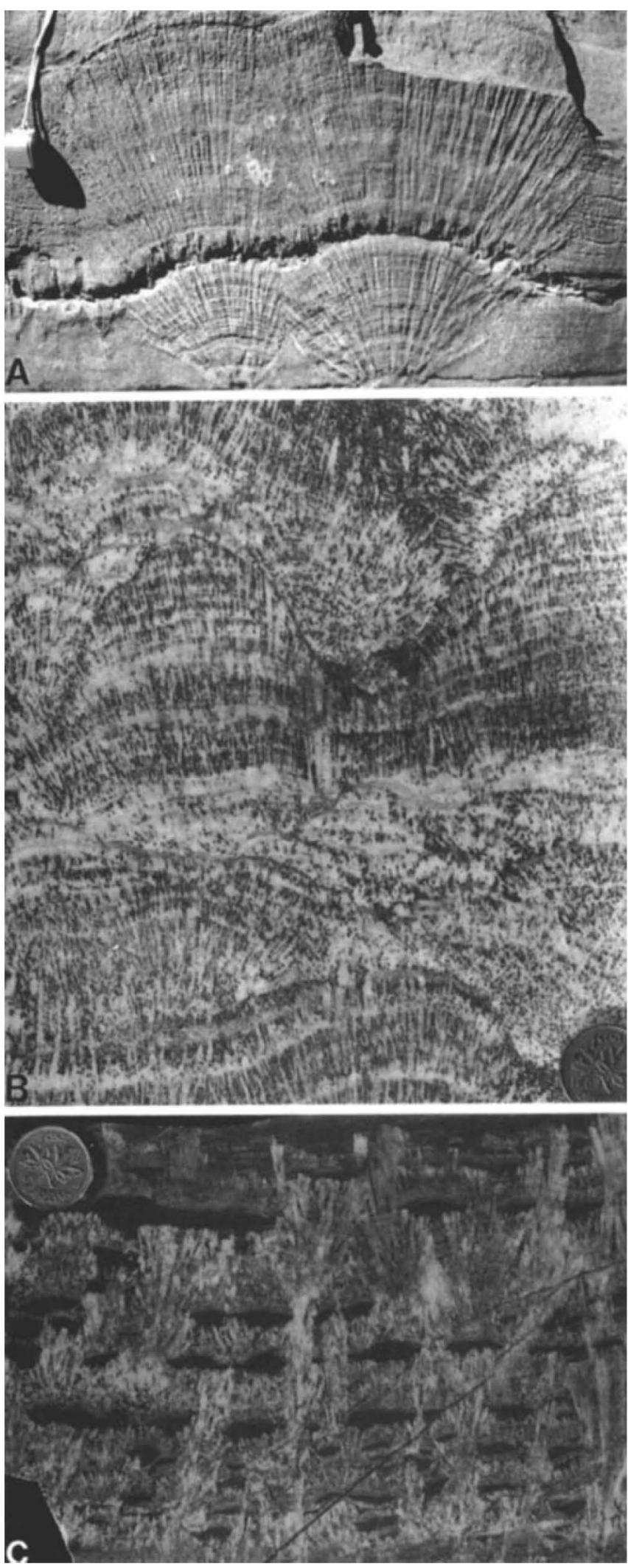

zone of active wave destruction. The reefs were constructed by the upward growth of stromatolites, as benthic microbes trapped and bound fine particles and/or induced carbonate precipitation. Abundant evidence for early cementation and/or precipitation of encrusting marine cement layers shows that most stromatolites formed rigid, wave-resistant structures (Grotzinger, 1986b, 1988, 1989). In some cases the reef itself may have formed by accretion of alternating microbial mat and seafloor cement layers (Kerans, 1982). In other cases, the microbial component was subordinate to massive volumes of seafloor-encrusting aragonite and calcite (Fig. 5; Sumner and Grotzinger, in press a; Grotzinger and Summer, in prep.). In this regard, individual stromatolites are analogous to the calcified fauna and flora of Phanerozoic reefs-they were directly responsible for the vertical accretion of the structure to form a topographically elevated surface relative to its non-reefal surroundings. As in the Phanerozoic, stromatolite reefs caused strong paleoenvironmental zonation of carbonate platforms (Grotzinger, 1988, 1989).

\section{Secular Trends in Precambrian Carbonates}

Archean and Proterozoic carbonates exhibit a first-order secular trend in the distribution of facies, particularly with respect to the volume of seafloor precipitates (Grotzinger, 1989, 1990; Knoll and Swett, 1990; Grotzinger and Kasting, 1993; Sumner and Grotzinger, in press a; Kah and Knoll, in prep). These precipitates are present as discrete seafloor encrustations of both inorganic and microbial origin. In the former case, the precipitates are morphologically and mineralogically identical to marine cements of Phanerozoic age (Grotzinger and Read, 1983; Grotzinger, 1986a, 1989; Fairchild et al., 1990; Sumner and Grotzinger, in press a), with the striking difference that they don't simply fill voids but are widespread as direct precipitates on the seafloor itself (Fig. 5). Seafloor encrusting precipitates are widespread in Archean successions, where they they may form discrete beds up to several meters thick (Grotzinger and Sumner, in prep.); cements beds as thin as 20 centimeters can be traced laterally for over 100 kilometers (Sumner, 1995). Individual aragonite botryoids (now calcite) typically have radii on the order of 10 's of centimeters (Fig. 5a), and in some cases were as great as 150 centimeters (Grotzinger et al., 1993; Sumner, 1995; Grotzinger and Sumner, in prep.).

$\leftarrow$

FIGURE 5-Precambrian sea floor-encrusting carbonates. (a) Large calcite-replaced aragonite fans, late Archean Campbellrand Subgroup, South Africa. Fans are developed on top of stromatolite reefs in a ramp setting. Outcrop photograph courtesy of Dawn Sumner. (b) Large dolomite-replaced aragonite fans, Paleoproterozoic Rifle Formation, northwest Canada. Fans are associated with transgressive stromatolite reefs developed within a largely siliciclastic shelf (Grotzinger and Friedman, 1989). Polished slab. (c) Calcite-replaced aragonite fans, Neoproterozoic Bushmansklippe Formation, Namibia. Fans occur in transgressive deposits which cover shelf carbonates (Hegenberger, 1993). 
Seafloor precipitates are widespread in Paleoproterozoic successions, but individual crystal fans and sheets more commonly have thicknesses measured in millimeters to centimeters rather than decimeters (Fig. 5b), and often form microdigitate tufa-like structures (Fig. 2a, b). Microdigitate structures are episodically abundant in $\mathrm{Me}-$ soproterozoic carbonate platforms as displayed, for example, in the ca. $1200 \mathrm{Ma}$ old Wumishan Formation, China (Cao, 1983; P. Hoffman, pers. comm., 1985; A. Knoll, pers. obs., 1992) and the slightly younger Society Cliffs Formation, Baffin Island (Kah and Knoll, in press) - but with rare exceptions (Fig. 5c; discussed below), macroscopically visible precipitate structures are unknown from younger Neoproterozoic rocks.

Stromatolites exhibit similar trends (Grotzinger, 1989, 1990; Knoll and Grotzinger, in prep.). The microfabrics of Archean and Paleoproterozoic stromatolites frequently contain evidence for in situ seafloor precipitation (Grotzinger and Read, 1983; Grotzinger, 1986a; Sumner and Grotzinger, in press a). Mesoproterozoic stromatolites less commonly show evidence of precipitated textures (Horodyski, 1975; Kerans, 1982; Komar, 1989) and Neoproterozoic stromatolites only rarely contain evidence for in situ precipitation rather than trapping-and-binding of loose sediment (Fairchild et al., 1990; Fairchild, 1991; Turner et al., 1993). The textures of precipitated Archean to Mesoproterozoic stromatolites are characterized by fine, even lamination, expressed microscopically as radial fibrous calcite (or dolomite) or mosaics of equant spar with relict radially-arranged fibers (Fig. $6 \mathrm{a}, \mathrm{b}$ ). In some cases, fabrics defined by alternating micritic and sparitic laminae are present (Fig. 6c). In Neoproterozoic stromatolites, precipitated carbonate occurs as micrite, locally abundant microscopic crystal fans nucleated at discrete points, Girvanella-like fabrics of interwoven calcified cyanobacterial filaments, and cement-encrusted thrombolitic mesoclots (Komar, 1989; Fairchild, et al., 1990; Knoll, et al., 1993b; Turner, et al., 1993; Grotzinger and Khetani, 1994).

$\rightarrow$

FIGURE 6-Textures of precipitated stromatolites, Paleoproterozoic Rocknest Formation, northwest Canada. (a) Photomicrograph of welllaminated domal stromatolite with palisades texture interpreted as evidence of former calcite (now dolomite). Crystals are elongate normal to lamination and optic axes are parallel to crystal boundaries. Note that the the stromatolite is dominated by encrusting, fibrous carbonate, with only local entrapment of clastic, micritic carbonate (arrow). (b) Photomicrograph of textural detail of columnar stromatolite featuring subequant crystals with randomly oriented optic axes, consistent with replacement of former aragonite (now dolomite). Crystal size is enhanced in clear areas, indicating aggrading neomorphism. Note that dark areas preserve palimpsest fibrous textures interpreted as relicts of former acicular crystals. (c) Photomicrograph of stratiform stromatolite with discontinuous, alternating light, sparitic laminae and dark, micritic laminae. Light laminae consist of subequant crystals with randomly oriented optic axes and are interpreted as former aragonite precipitates. Note that outlines of former crystals and/or crystal bundles are preserved at the tops of light laminae. The fabric is interpreted to represent episodic accretion of encrusting, precipitated layers, followed by trapping and binding of clastic, micritic carbonate.
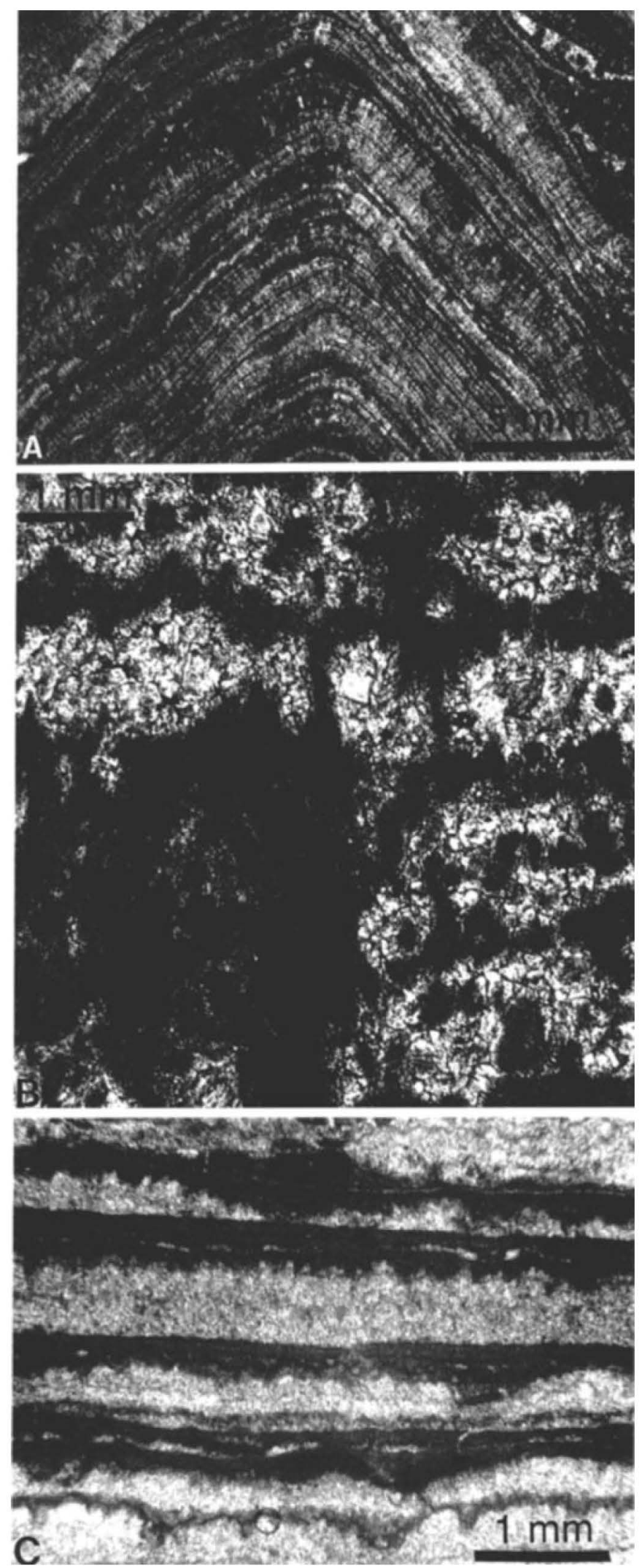
The broad pattern that emerges is a distinct, long-term decrease in the abundance of inorganically precipitated marine aragonite and calcite paralleled by a decline in the abundance of precipitated microbialites (Grotzinger, 1989, 1990; Grotzinger and Kasting, 1993; Semikhatov and Raaben, 1993). The simplest interpretation is that during the Precambrian, oceanic surface water was substantially oversaturated with respect to calcium carbonate, well above the factor of 3-5 that is typical of the oceans today (Li et al., 1969). The saturation state of ocean surface water is inferred to have been highest in the Archean, declining through the Paleoproterozoic and Mesoproterozoic, and reaching near-Phanerozoic values only during the the later Neoproterozoic or Cambrian (Grotzinger, 1989; Fairchild et al., 1990; Grotzinger and Kasting, 1993; Knoll et al., 1993a). Grotzinger and Kasting (1993) noted that this interpretation is consistent with suggestions that the partial pressure of atmospheric carbon dioxide was much greater early in Earth history (Kasting, 1987) and that the total inorganic carbon and alkalinity in sea water may have been higher as a result. Theoretical arguments have been presented (Kempe and Degens, 1985; Kempe and Kazmierczak, 1994) which also favor elevation of alkalinity in early "soda" oceans; whatever the merits of the "soda" ocean scenario for earliest Earth history, it is unlikely to be applicable to later Archean and Proterozoic successions (Holland, 1984; Grotzinger and Kasting, 1993).

The Precambrian decrease in the saturation state of seawater is thought to relate to at least two factors: 1) the long-term transfer of inorganic carbon from the atmosphere and ocean to the continents as a result of the formation, by $2.5-2.0 \mathrm{Ga}$, of large and stable continents capable of preserving substantial limestone and dolostone deposits, and 2) a major decrease in concentration of reduced (and therefore more soluble) iron and manganese in seawater related to a Paleoproterozoic increase in oxygen amd sulfate levels in the atmosphere/surface seawater system (Cloud, 1968; Holland and Beukes, 1990). Sumner and Grotzinger (in press b) have postulated that $\mathrm{Fe}^{2+}$ and $\mathrm{Mn}^{2+}$ acted in the same manner as $\mathrm{Mg}^{2+}$ does in inhibiting calcium carbonate precipitation (c.f. Berner, 1975; Mucci and Morse, 1983). The major decline of seafloor precipitates, both inorganic and microbial, occurs hundreds of millions of years before the Precambrian-Cambrian boundary and, thus, cannot be related to the advent of carbonate-secreting metazoans and higher algae. In terms of its effects on carbonate facies and microfabric pattern, this decline is as significant as the Cambrian radiation of skeletonized organisms and the Mesozoic evolution of calcareous microplankton.

The trend discussed above is considered only to be a first-order relationship and does not rule out transient reversals in response to short-term events. There are late Archean platforms which are dominated by muds, intraclasts, ooids and/or non-precipitated stromatolites and lack the abundant encrusting precipitates that define the late Archean norm. Similarly, the Neoproterozoic record contains exceptions to the general dearth of macroscopic seafloor encrustations and other precipitated carbonates. The exceptions occur in the so-called cap carbonates and associated rocks that overlie Neoproterozoic glaciogenic rocks. As discussed in detail below, the late Neoproterozoic reprise of carbonate textures more characteristic of early Earth history provides an important clue to the interpretation of late Permian reef carbonates.

\section{STRATIFICATION, ANOXIA, AND CARBONATE PRECIPITATION}

\section{The Early Precambrian Ocean}

It is generally thought that the Archean ocean was anoxic except for a thin oxidizing surface layer sustained by cyanobacteria (Cloud, 1968; Roscoe, 1969; Holland, 1984; Morris and Trendall, 1988; Beukes and Klein, 1993). Paleosol chemistry and carbon isotopic data suggest that atmospheric oxygen levels increased from less to somewhat more than $1 \%$ of the present day level at about $2.1 \mathrm{Ga}$ (Holland and Beukes, 1990; DesMarais et al., 1992; Karhu, 1993); however, the continued precipitation of iron formation until $1.85 \mathrm{Ga}$ indicates that deep ocean anoxia persisted at least until that time.

To explain the precipitation of iron formation, Beukes and Klein (1993) developed a model that invokes a densitystratified ocean system with oxic surface waters and anoxic deeper waters enriched in dissolved ferrous iron. Within this ocean, the precipitation of iron-bearing minerals takes place along an oxycline determined by the downward flux of organic matter from the photic zone and the upward transport of ferrous iron from deeper waters. Where organic fluxes are high, black shales accumulate; where the organic flux is low, ferrous iron is oxidized upon contact with oxic surface waters, causing precipitation of iron oxides along the chemocline (Fig. 7a; Beukes and Klein, 1993).

By the Mesoproterozoic Era, the ocean is thought to have become mixed (Fig. 7c); however, the progressive oxidation of the deep ocean was not irreversible. Ocean stratification events are known from several intervals of the Phanerozoic (Degens and Stoffers, 1976; Arthur and Sageman, 1994), and successive intervals of ocean stagnation that occurred during the late Neoproterozoic Era (Fig. 7d; Knoll et al., 1986; Derry et al., 1992; Knoll, 1992) are associated with the transient reappearance of iron formations (Young, 1976).

The oceanographic history invoked to explain the secular distribution of iron formation can also account for the record of Precambrian carbonate sedimentation (see Kempe, 1990). It is well known that anoxic deep waters in stratified seas and lakes are apt to experience substantial increases in carbonate alkalinity as a result of bicarbonate production during bacterially-mediated sulfate reduction and ammonia formation (reactions 1-5 reported in Goyet et al., 1991; see also Canfield and Raiswell, 1991; Kempe and Kazmierczak, 1994). In the Black Sea, for example, microbial processes generate a carbonate alkalinity on the order of 3-4 times greater than that of the open ocean at similar depths (on a constant salinity basis; Goyet et al., 1991). Upwelling of anoxic bottom waters with elevated 
$\mathrm{HCO}_{3}^{-}$and $\mathrm{CO}_{3}^{--}$concentrations can result in prolific calcium carbonate precipitation upon degassing and mixing with $\mathrm{Ca}^{++}$-rich surface waters (Kempe, 1990).

We suggest that precipitation of late Archean and $\mathrm{Pa}$ leoproterozoic seafloor-encrusting aragonite and calcite deposits occurred during episodic upwelling of anoxic deep waters with elevated alkalinities. Even if sulfate concentration were low in early oceans, deep water alkalinity could have reached high values because of bicarbonate generated by the microbial reduction of iron ferrihydroxides formed at the oxycline (Canfield and Raiswell, 1991). Upwelling deep waters would have mixed with calciumcontaining surface waters, causing widespread precipitation both within stromatolite reef complexes (where microbial decomposition within mats would have induced carbonate nucleation and growth) and across the shelf as discrete seafloor cement beds. Available geologic data (Grotzinger, 1989; Grotzinger and Kasting, 1993) fit a mod$\mathrm{el}$ in which precipitation related to the upwelling of deep water supplemented that which occurred on a regular basis from perpetually supersaturated shallow water (Grotzinger and Kasting, 1993). This interpretation contrasts with that of Kempe and Degens (1985), who argued that Archean ocean surface waters were depleted in calcium, similar to modern alkaline lakes. While we agree that anoxic bottom waters provide a favorable environment for producing alkalinities that are elevated relative to coexisting surface waters, there is as yet little empirical evidence for a lasting "soda" ocean (see Kempe, 1990; Kempe and Kazmierczak, 1994).

The oxidation and mixing of deep waters would have significantly reduced the depth-dependent alkalinity gradient. Thus, it is not surprising that the disappearance of evidence for deep water anoxia during Mesoproterozoic time (Beukes and Klein, 1993; Fig. 7c) is matched by a conspicuous decrease in the volume of aragonite and calcite precipitated directly on the seafloor (Grotzinger, 1989; Grotzinger, 1994; Grotzinger and Kasting, 1993). In Mesoproterozoic oceans, macroscopic precipitates occur principally in peritidal settings where oversaturation was enhanced by evaporation.

\section{Neoproterozoic "Cap Carbonates" and the Isotopic} Signature of Upwelling Bottom Water

The late Neoproterozoic reprise of iron formation and precipitate-rich carbonates (Fig. 7d, e) is noteworthy, particularly because it occurs in association with both glaciogenic rocks and major excursions in the carbon-isotopic composition of surface waters. Viewed individually, each of these features might be interpreted in several ways; however, considered as a stratigraphically related suite, later Neoproterozoic phenomena are most parsimoniously interpreted as sedimentary consequences of ocean stratification and subsequent turnover (Kaufman et al., 1991). That is, conditions widely characteristic of the Archean and Paleoproterozoic ocean returned episodically during the later Neoproterozoic Era.

Tillites and associated glaciogenic facies have long been
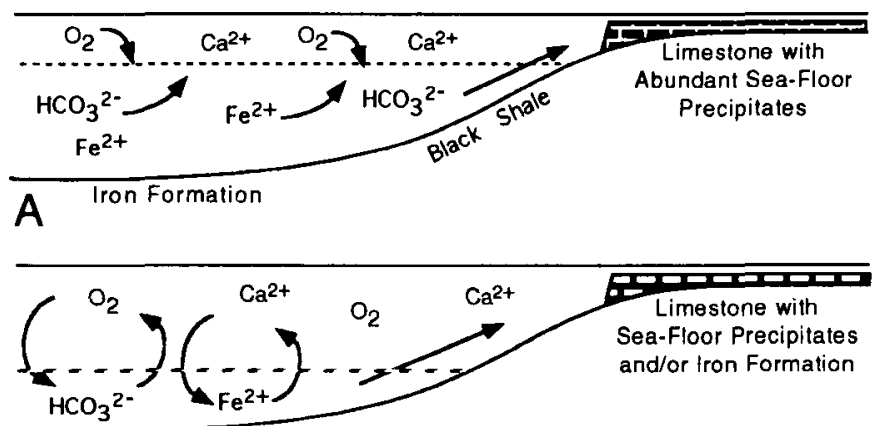

B

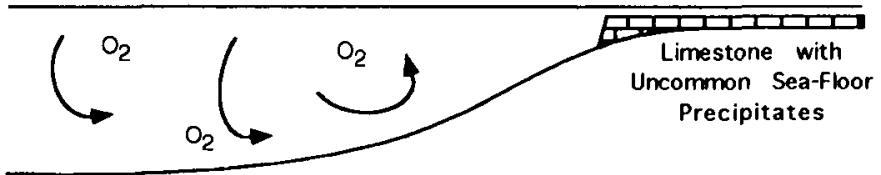

C

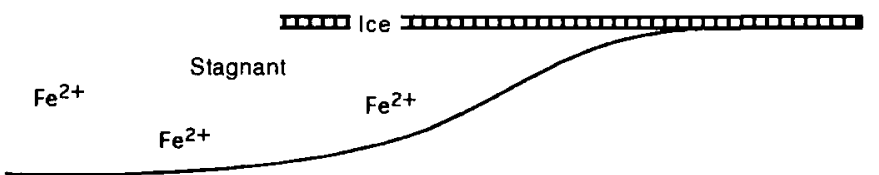

D

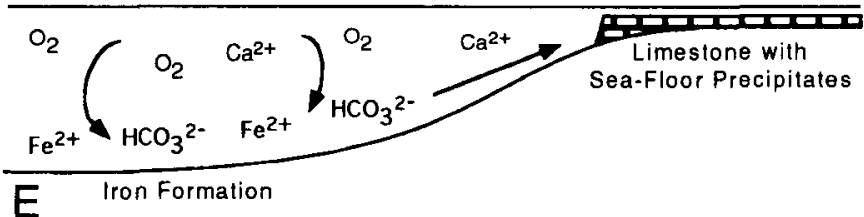

FIGURE 7-Paleoceanographic models for carbonate deposition from late Archean through Neoproterozoic time. (a) Archean to Paleoproterozoic $(2.7-2.0 \mathrm{Ga})$ stratified ocean featuring deep-water iron formation deposition which results from the precipitation of iron oxide at the chemocline. Carbonate deposition occurs above a shallow CCD where supersaturation is high; episodic upwelling of deep water with elevated alkalinity results in locally prolific carbonate precipitation in the form of seafloor-encrusting aragonite and calcite. (b) Middle Paleoproterozoic $(2.0-1.8 \mathrm{Ga})$ ocean with breakdown of chemocline. Iron formations and limestones are deposited on shallow shelves due to mixing of deep and shallow water. Carbonate facies include widespread seafloor crusts, but less abundant than in the late Archean. (c) Mesoproterozoic to middle Neoproterozoic (1.6 to $0.8 \mathrm{Ga}$ ) wellmixed ocean. Carbonate precipitation occurs on shallow-water platforms and seafloor crusts are significantly reduced in comparison to older carbonates. Iron formation is absent. (d) late Neoproterozoic 0.8 to $0.6 \mathrm{Ga}$ ) with deep ocean stagnation and buildup of ferrous iron and alkalinity. (e) late Neoproterozoic ocean immediately following deglaciation. "Cap carbonates" are formed as a result of mixing upwelling, isotopically-depleted, alkaline bottom water and calcium-rich surface water. Transgressing seas were highly oversaturated with respect to calcium carbonate and precipitation occurred directly on top of glacial deposits and pavements with little or no intervening siliciclastic sediment. Adapted from Beukes and Klein (1993) and Kempe (1990). 
known to occur in later Neoproterozoic successions (e.g., Hambrey and Harland, 1985), and from the time they were first recognized, their intimate stratigraphic association with carbonates was considered paradoxical (e.g., Schermerhorn, 1974). Particularly puzzling are the "cap carbonates"--texturally unusual, often pinkish dolomites (less commonly, limestone) that form distinctive beds several meters thick above many Neoproterozoic tillites. The globally distributed cap carbonates are extraordinary in that they were deposited directly on top of the glacial deposits, implying that carbonate sedimentation occurred at the onset of transgression over previously glaciated landscapes (Knoll and Walter, 1992). In keeping with this interpretation, cap carbonates can be distributed more widely than the glaciogenic successions they cover (e.g., Aitken, 1989), and carbonate units texturally similar to cap carbonates are found in the predicted stratigraphic position in places where underlying tillites are absent (Hegenberger, 1993).

In most cases, cap carbonates are remarkably pure; they commonly appear as vaguely laminated dolomicrospar showing evidence of rapid lithification, but locally include seafloor encrustations and cements of originally aragonitic, centimeter- to decimeter-scale crystal fans (Fig. 5c; Narbonne et al., 1994). Stromatolites may occur locally (Walter and Bauld, 1983), but are not common. Walter and Bauld (1983) proposed that the apparent discordance between tillites and carbonates can be explained in terms of stromatolite accretion in cold lakes, as occurs today in Antarctica; however, this mechanism cannot account for either the texture or the distribution of most cap carbonates. In contrast, Tucker (1986), Singh (1987) and Fairchild (1993) suggested that the carbonates might have precipitated during warm interglacial intervals, implying that Neoproterozoic ice ages were terminated rapidly. The thermodynamic effect of warming in decreasing the solubility of carbonate in seawater must have contributed to the formation of cap carbonates. However, this effect was very likely supplemented by an additional factor-the overturn of previously stratified ocean basins, which forced the upwelling of anoxic, alkaline deep water (Fig. 7d, e).

The sedimentology of cap carbonates is consistent with this hypothesis, and independent evidence for deep ocean anoxia comes from the iron formations found in association with Neoproterozoic tillites (Young, 1976; Beukes and Klein, 1993). However, the strongest evidence for sequential ocean stratification and turnover is provided by carbon isotopic data. $\delta^{13} \mathrm{C}$ values for later Neoproterozoic platform carbonates deposited prior to glaciation are unusually high -+8 to $+11 \% \%$ and locally higher, while cap carbonates have values of -2 to $-6 \% \%$ (Kaufman and Knoll, in press, and references therein). Co-occuring organic carbon shows the same secular variation, supporting petrological, geochemical, and geographic data that the isotopic signatures faithfully record secular changes in the isotopic composition of the surface ocean (Knoll et al., 1986; Narbonne et al., 1994; Kaufman and Knoll, 1995).

The surface waters of stratified oceans may become enriched in ${ }^{13} \mathrm{C}$ because of export of large volumes of ${ }^{13} \mathrm{C}$ depleted organic matter to anoxic bottom waters and the sediments beneath them (Deuser, 1970). Bacterial sulfate reduction of organic matter in the deep, anoxic water column produces $\mathrm{HCO}_{3}{ }^{-}$and $\mathrm{CO}_{3}{ }^{--}$depleted in ${ }^{13} \mathrm{C}$. The magnitude and inferred duration of pre-glacial $\mathrm{C}$-isotopic excursions in Neoproterozoic successions are unusual, implying a protracted build-up of isotopically light deep ocean alkalinity. Remixing of this alkalinity-laden deep water into the surface ocean would result in the precipitation of carbonates whose isotopic composition would be determined primarily by the composition of the large, deep alkalinity reservoir (Arthur, 1979; Holser, 1984; Kump, 1991).

Thus, ocean stratification (Fig. 7d) can account for measured C-isotopic compositions and the transport of $\mathrm{Fe}^{2+}$ in solution to sites of iron formation deposition; additionally, the transfer of $\mathrm{CO}_{2}$ from the atmosphere to the deep sea by biological pumping provides a possible mechanism to aid the onset of continental glaciation (Kaufman et al., 1993). Subsequent large-scale upwelling of deep waters into the surface ocean provides an explanation for the observed C-isotopic shift and, to come full circle, a mechanism for transiently restoring the highly oversaturated conditions needed to produce cap carbonates (Fig. 7e). How melting glaciers might have induced ocean mixing remains unclear; however, the very assumption that deglaciation drove oceanic overturn may be misleading. The growth of continental ice sheets may have forced oceanic turnover by facilitating the resumption of cold water generation, and the release to the atmosphere of $\mathrm{CO}_{2}$ previously stored in the deep ocean could, itself, have initiated deglaciation.

\section{Late Permian Carbonate Precipitation and Reef Growth}

Could a younger episode of protracted ocean stratification help to explain the Late Permian reefs of west Texas and elsewhere? Many authors have interpreted the Late Permian ocean to be stratified, with anoxic bottom water (Magaritz and Schulze, 1980; Magaritz and Turner, 1982; Magaritz et al., 1983; Holser, 1984; Malkowski et al., 1989; Wignall and Hallam, 1992; Erwin, 1994; Isozaki, 1994; Kajiwara et al., 1994). Whether or not the entire deep ocean was devoid of oxygen, large volumes of anoxic deep water appear to have developed in narrow ocean basins, including a Tethys whose long axis paralleled the equator. In the vast Panthallasic Ocean, sluggish circulation of relatively warm, oxygen-poor deep waters would additionally have facilitated the development of extensive oxygen-depleted water masses away from the surface mixing zone and active sites of downwelling.

Support for the interpretation of ocean stratification comes from the unusual enrichment of ${ }^{13} \mathrm{C}$ in Late Permian carbonates and organic matter (Baud et al., 1989; Magaritz et al., 1992; Scholle, 1995). $\delta^{13} \mathrm{C}$ values of carbonates are relatively high for much of the late Paleozoic, but during the upper Guadalupian, they soared to values as high as +8 per mil, a peak matched during the past $2000 \mathrm{Ma}$ only by the late Neoproterozoic carbonates discussed in the 
previous section. A sharp decrease to +4 per mil in the $\mathrm{C}$-isotopic curve for the back-reef carbonates equivalent to the upper Capitan (Garber et al., 1989) is consistent with a model involving episodic incursion of alkalinityenriched, ${ }^{13} \mathrm{C}$-depleted basinal waters onto the adjacent platform. Other C-isotopic data from numerous localities support the possibility of two or more excursions to less positive values in the late Permian, prior to the epochending drop near the Permo-Triassic boundary (Baud et al., 1989; Gruszczynski et al., 1989; Magaritz et al., 1992; Erwin, 1994). Although the first-order features of the late Permian $\mathrm{C}$-isotopic curve are probably global in nature, smaller negative excursions in individual sections may record local (and hence asynchronous) "burping" of ocean deep water, rather than whole-ocean turnover (well discussed by Kempe and Kazmierczak, 1994). Unfortunately, further interpretation is limited by the isotopic data themselves because of low sampling densities (the most highly resolved studies involve 1-2 samples per 10 meters of section; Baud et al., 1989), and the presence of large gaps in the data (resulting from diagenetic resetting, unsuitable lithologies, or unconformities), across which isotopic trends are linearly interpolated (e.g., Gruszczynski et al., 1989; see Scholle, 1995, for discussion).

It is also important to recognize that both the Capitan and Magnesian Limestone reefs developed adjacent to small basins (Delaware and Zechstein) that were partially isolated from the world ocean. These basins are each thought to have been stratified at times, with anoxic bottom waters that underwent intermittent overturn (Newell et al., 1953; Peryt, 1978; Smith, 1980, 1981; Magaritz and Turner, 1982; Magaritz et al., 1983). Thus, a complex scenario must be entertained in which the water responsible for precipitation of reefal limestone may have undergone a two-stage evolutionary process, first in the world ocean and then in the Delaware and Zechstein basins. Furthermore, because of the global long-term lowstand in sea level, carbonate sedimentation was restricted to the periphery of the supercontinent. The saturation state of surface seawater may, thus, have been unusually high due to the following factors:

1) the reduced shelf space for carbonate precipitation due to the global, long-term lowstand in sea level at this time (Vail et al., 1977). In the absence of pelagic carbonate-secreting organisms, reduced shelf space would force an increase in the saturation state of sea water due to the limited space available for precipitation.

2) an increase in continental erosion resulting from the global lowstand in sea level. This would lead to an increase in the the flux of $\mathrm{Ca}^{++}$and alkalinity to the oceans due to weathering of older, subaerially exposed limestones.

3) stratification of at least part of the global ocean and Delaware/Zechstein basins, allowing development of anoxic bottom waters with elevated alkalinities. As discussed above, mixing of shallow and deep waters would result in prolific carbonate precipitation.

The strength of this model lies in the potential coincidence of all three of these factors. Thus, the predicted magnitude of the carbonate precipitation anomaly may have been substantially higher than at other times in the Phanerozoic. For example, the Cretaceous is considered to have been a time in which the global ocean was episodically stratified with anoxic, probably alkaline bottom water (Zachos and Arthur, 1986). However, because the Cretaceous was a time of global high stand in sea level (Haq et al., 1987) there was no coincident increase in the flux of continentally-derived calcium or alkalinity to the ocean; in fact, continental flooding may have resulted in a decrease in the saturation state of seawater due to widespread carbonate precipitation (Berner et al., 1983; Wilkinson et al., 1985). Furthermore, during the Cretaceous, planktonic foraminifera and calcareous nannoplankton produced vast quantities of carbonate in the open ocean, lessening the constraint of available shelf space on global saturation state. Consequently, although carbonate precipitation was also widespread at this time, the anomalous volumes of inorganic and microbial precipitates seen in the Late Permian are not present in Cretaceous reef or shelf carbonates (Simo, 1994).

Newell et al. (1953) and Babcock (1977) provided sedimentologic and paleontologic evidence for stratification of the the Delaware Basin. This subsequently was confirmed by stable isotopic data from Delaware Basin sediments which indicated that the stratified waters were in partial communication with the world ocean, yet were restricted enough to be sensitive to fluctuations in continental runoff (Magaritz et al., 1983). We suggest that this circumstance was ideal for producing anomalous volumes of carbonate precipitation along the periphery of the basin. This model is shown in Figure 8. As first suggested by Newell et al. (1953), the early history of the Delaware Basin may have featured free circulation due its overall shallow depth (Fig. 8a). Communication with the open ocean via the Hovey Channel would have allowed influx of highly saturated ocean water. It is interesting to note that the early history of the reef (Goat Seep and lower Capitan phase), while marked by abundant marine cementation, nevertheless lacks the extraordinary volumes of cement that characterize the middle and upper parts of the reef. Consequently, we infer that this stage of the reef records precipitation from mostly unmodified, highly supersaturated global ocean waters.

With time, the Delaware Basin became much deeper as a result of differential subsidence of the basin coupled with upward growth of the reef. Vertical stratification of the basin occurred as a result of this deepening and increased regional aridity (Fig. 8b; Newell et al., 1953). In consequence, highly supersaturated waters entering the basin through Hovey Channel underwent further evolution in the stratified Delaware Basin. As basinal waters enriched in carbonate alkalinity mixed with already highly saturated surface waters, massive volumes of inorganic seafloor-encrusting aragonite and subordinate calcite were precipitated. Simultaneously, cyanobacterial mats became calcified to form Collenella stromatolites and encrusting masses of Archaeolithoporella. Whereas earlier stages of reef growth (Goat Seep-lower Capitan) had featured dis- 


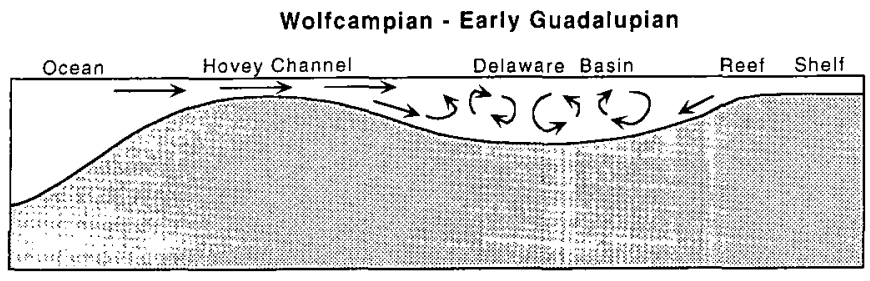

A

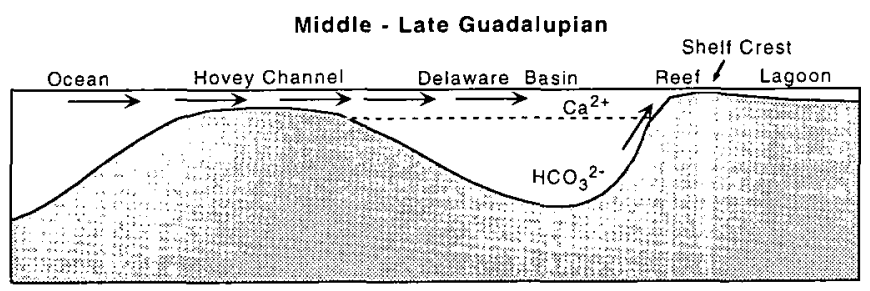

B

FIGURE 8 - Inferred circulation of seawater within the Delaware Basin, (a) during Wolfcampian through early Guadalupian time, and (b) during middle to late Guadalupian time. Adapted from Newell et al. (1953). The early, shallow basin was well ventilated due to convective, possibly seasonal overturn. With time, the basin progressively deepened due to differential subsidence and keep-up sedimentation of the flanking carbonate platform. Overturn of deep waters became more and more difficult and hypersaline, anoxic, and mildly alkaline bottom waters developed. Episodic upwelling of these waters along the basin margin resulted in massive seafloor carbonate precipitation as inorganic crusts and calcified microbialites. The evolution of the reef during Guadalupian time, recorded by an increase in the importance of marine precipitates, is interpreted to reflect the progressive stratification of the basin and development of bottom waters with greater alkalinity. This model would be equally applicable to the Zechstein basin and flanking Magnesian Limestone reef.

integration of the fragile bryozoan-sponge-algal benthos to form floatstone-packstone banks, the addition of great volumes of inorganic and microbial precipitates provided the binding glue that was necessary for the construction of a rigid frame and reef core. The primary porosity of the reef was high owing to the stick-like and platy geometry of the bryozoans, and this provided suitable environments for cryptobiontic sponges (Wood et al., 1994).

We suggest that the fabric of the reef core is the result of inorganic and microbial encrustation of geometrically complex, but otherwise fragile metazoans. This interpretation parallels that of previous authors (Babcock, 1977; Cys et al., 1977; Schmidt, 1977) but differs in assigning even greater importance to the role of calcified microbialites as represented by Collenella and Archaeolithoporella, and, possibly, the microbial micrites mentioned by Wood et al. (1994). In comparison with early Precambrian reefs, there is good reason to believe that if metazoans and calcifying higher algae had not been present, an impressive reef core would still have been formed because of the high growth potential of seafloor crusts and microbialites. However, the unique texture of the upper Capitan reef core owes its origin to the growth of inorganic and microbial precipitates in the presence of a higher level biota, without which the high proportion of primary cavities in the reef core would not have been possible. Precambrian reefs are notoriously low in primary porosity because they grow exclusively through encrustation and sediment binding (Grotzinger, 1988, 1989).

\section{CONCLUSIONS}

In the interpretation of ancient carbonate build-ups, the present provides only a limited perspective that must be augmented by the distant mirror of the Earth's early geological record. In this enlarged view, the Recent and the Archean define endmember states of ocean oxygenation, providing new avenues for the interpretation of anomalous, precipitate-rich carbonates in both Late Permian reefs and terminal Proterozoic cap carbonates. In the case of the Capitan and Magnesian Limestone reefs, dependence on the Recent for sedimentological analogs has encouraged an overemphasis on the framework contributions of animals and putative calcareous algae and an underappreciation of the capacity of precipitated microbialites and seafloor cements to build reef-like structures. Early Precambrian build-ups demonstrate the tremendous reef-building potential of carbonate precipitates when suitably oversaturated surface waters mix with upwelling deep water charged with alkalinity by bacterial sulfate reduction and/ or iron reduction.

In fact, the Late Permian reefs appear to be hybrids. They are Precambrian-like in that abundant inorganically precipitated seafloor crusts, marine cements, and precipitated microbialites were essential for the construction of a reef frame. In their absence, the build-up would probably have evolved as a bioclastic bafflestone. On the other hand, the texture and ecological complexity of the build-ups resemble those of modern reefs because, given the structural support of precipitated carbonate, otherwise fragile metazoans and algae were able to construct a porous frame with large cavities that could support a well-developed cryptos.

Today, marine stromatolites grow overwhelmingly by trapping and binding; however, this mode of accretion does not provide a representative view of either all Phanerozoic or many Precambrian stromatolites. Our perspective on Late Permian reefs suggests that precipitation textures might be sought in other Phanerozoic stromatolites associated stratigraphically with episodes of oceanic anoxia-the Late Devonian comes immediately to mind. In the Late Permian, precipitation mechanisms may help to explain the remarkably high rate of reef growth-one of the fastest known in the Phanerozoic Eon (Garber et al., 1989). Finally, comparative analyses of facies development in older reef systems may provide a resolution of long-standing controversies concerning the bathymetry and evolution of the Capitan and other late Permian platforms.

\section{ACKNOWLEDGMENTS}

We thank M. Harris, C. Kerans, L. Pray, and D. Smith, and M. Tucker for helpful discussions on late Permian 
reefs, providing useful suggestions, and supplying rock samples and photographs. Helpful reviews of the manuscript were provided by R. Bambach, J. Bartley, D. Canfield, J. Kasting, J. Kaufman, B. Kirkland-George, L. Kump, P. Hoffman, L. Pray, D. Smith, D. Sumner, and R. Wood. PALAIOS reviewers P. Scholle, B. Wilkinson, and two anonymous readers also provided very useful critiques. Financial support during preparation of the manuscript was provided by NASA Grants NAGW2795 to JPG and NAGW893 to AHK.

\section{REFERENCES}

ACHaUer, C., 1969, Origin of the Capitan Formation, Guadalupe Mountains, New Mexico and Texas: American Association of Petroleum Geologists Bulletin, v. 53, p. 2314-2323.

AITKEN, J.D., 1989, Uppermost Proterozoic formations in central Mackenzie Mountains, Northwest Territories: Geological Survey of Canada, Bulletin 368, 26 p.

Alvarez, W., 1986, Toward a theory of impact crises: EOS, Transactions of the American Geophysical Union, v. 67, p. 649-658.

ARTHUR, M.A., 1979, Paleoceanographic events-Recognition, resolution, and reconsideration: Reviews in Geophysics and Space Physics, v. 17, p. 1474-1494.

Arthur, M.A., and SAGEman, B.B., 1994, Marine black shales: Depositional mechanisms and environments of ancient deposits: Annual Reviews in Earth and Planetary Sciences, v. 22, p. 499-551.

BAARS, D.L., 1964, Modern carbonate sediments as a guide to old limestones: World Oil, v. 158, p. 95-100.

BABCoCK, J.A., 1977, Calcareous algae, organic boundstones, and the genesis of the Upper Capitan Limestone (Permian, Guadalupian) Guadalupe Mountains, west Texas and New Mexico: in HilemaN, M.E., and Mazzullo, S.J., eds., Upper Guadalupian Facies, Permian Reef Complex, Guadalupe Mountains, New Mexico and West Texas: Field Conference Guidebook 77-16: Permian Basin Section-Society of Economic Paleontologists and Mineralogists, $p$. 3-44.

BABCoCK, J.A., and YuREwicz, D.A., 1989, The massive facies of the Capitan limestone, Guadalupe mountains, Texas and New Mexico: in HARris, P.M., and Grover, G.A., eds., Subsurface and Outcrop Examination of the Capitan Shelf Margin, Northern Delaware Basin; SEPM Core Workshop No. 13: Society of Economic Paleontologists and Mineralogists, p. 365-372.

Baud, A., Magaritz, M., and Holser, W.T., 1989, Permian-Triassic of the Tethys: Carbon isotopic results: Geologische Rundschau, v. 78, p. $649-677$.

BERNER, R.A., 1975, The role of magnesium in the crystal growth of calcite and aragonite from sea water: Geochimica et Cosmochimica Acta, v. 39 , p. $489-504$.

Berner, R.A., LASAGA, A.C., and Garrels, R.M., 1983, The carbonate-silicate geochemical cycle and its effect on atmospheric carbon dioxide over the past 100 million years: American Journal of Science, v. 283, p. 641-683.

Bertrand-SAfarti, J., and Monty, C., eds., 1994, Phanerozoic Stromatolites II: Elsevier, Amstrerdam, 471 p.

Beukes, N.J., and KLEIN, C., 1993, Models for iron-formation deposition: in Schopf, J.W., and Klein, C., eds., The Proterozoic Biosphere: Cambridge University Press, Cambridge, p. 147-151.

CANFIELD, D.E., and RAISWELL, R., 1991, Carbonate precipitation and dissolution: its relevance to fossil preservation: in ALLISON, P.A. and Briggs, D.E.G., eds., Taphonomy: Releasing the Data Locked in the Fossil Record: Plenum Press, London, p. 411-453.

CAO, R.-J., 1983, Microflora of Precambrian-influence on stromatolite morphology: Bulletin of the Nanjing Institute of Geology and Paleontology, Academia Sinica, v. 6, p. 1-7.
Chafetz, H.S., and Buczynski, C., 1992, Bacterially induced lithification of microbial mats: PALAIOS, v. 7, p. 277-293.

ChafeTz, H.S., and FolK, R.L., 1984, Travertines: Depositional morphology and the bacterially constructed constituents: Journal of Sedimentary Petrology, v. 54, p. 289-316.

Cloud, $P_{\text {., }} 1968$, Atmospheric and hydrospheric evolution on the primitive earth: Science, v. 160, p. 729-736.

Cronoble, J.M., 1974, Biotic constituents and origin of facies in Capitan reef, New Mexico and Texas: Mountain Geologist, v. 11, p. 95-108.

Cys, J.M., Toomey, D.F., Brezina, J.L., Greenwood, E., Groves, D.B., Klement, K.W., Kullman, J.D., McMillan, T.L., SchmidT, V., SNEED, E.D., and WAGNER, L.H., 1977, Capitan reef-Evolution of a concept: in Hileman, M.E., and Mazzullo, S.J., eds., Upper Guadalupian Facies, Permian Reef Complex, Guadalupe Mountains, New Mexico and West Texas: Field Conference Guidebook 77-16: Permian Basin Section-Society of Economic Paleontologists and Mineralogists, p. 201-322.

Degens, E.T., and Stoffers, P., 1976, Stratified waters as a key to the past: Nature, v. 263, p. 22-27.

DerRy, L.A., KaufMan, A.J., and JACobsen, S.B., 1992, Sedimentary cycling and environmental change in the Late Proterozoic: Evidence from stable and radiogenic isotopes: Geochimica et Cosmochimic Acta, v. 56, p. 1317-1329.

Deuser, W.C., 1970, Carbon-13 in Black Sea waters and implications for the origin of hydrogen sulfide: Science, v. 268, p. 1575-1577.

DesMarais, D.J., Strauss, H., Summons, R.E., and Hayes, J.M., 1992, Carbon isotopic evidence for the step-wise oxidation of the Proterozoic environment: Nature, v. 359, p. 605-609.

DunhaM, R.J., 1969, Vadose pisolite in the Capitan reef (Permian), New Mexico and Texas: in Friedman, G.M., ed., Depositional Environments in Carbonate Rocks: Society of Economic Paleontologists and Mineralogists, Publication 14, p. 182-191.

Dunham, R.J., 1972, Capitan reef, New Mexico and Texas: Facts and questions to aid interpretation and group discussion: Permian Basin Section-Society of Economic Paleontologists and Mineralogists, Publication 72-14, 297 p.

Erwin, D.H., 1994, The Permo-Triassic Extinction: Nature, v. 367, p. $231-236$

FAIRCHILD, I.J., 1991, Origins of carbonate in Neoproterozoic stromatolites and the identification of modern analogues: Precambrian Research, v. 53, p. 281-299.

FAIRCHILD, I.J., 1993, Balmy shores and icy wastes: The paradox of carbonates associated with glacial deposits in Neoproterozoic times: Sedimentology Review, v. 1, p. 1-15.

Fairchild, I.J., Marshall, J.D., and Bertrand-Safarti, J., 1990, Stratigraphic shifts in carbon isotopes from Proterozoic stromatolitic carbonates (Mauritania): Influences of primary mineralogy and diagenesis: American Journal of Science, v. 290-A, p. 46-79.

Flügel, E., and ReINHARdT, J., 1990, Uppermost Permian reefs in Skyros (Greece) and Sichuan (China): Implications for the Late Permian extinction event: PALAIOS, v. 4, p. 502-518.

Flügel, E., Kochansky-Devide, V., and Ramovs, A., 1984, A middle Permian calcisponge/algal/cement reef: Straza near Bled, Slovenia: Facies, v. 10, p. 179-256.

Garber, R.A., Grover, G.A., and Harris, P.M., 1989, Geology of the Capitan shelf margin-Subsurface data from the northern Delaware Basin: in Harris, P.M., and Grover, G.A., ed., Subsurface and Outcrop Examination of the Capitan Shelf Margin, Northern Delaware Basin; SEPM Core Workshop No. 13: Society of Economic Paleontologists and Mineralogists, p. 3-269.

GeldSETzer, H.H.J., JAMEs, N.P., and TebButT, G.E., 1988, ReefsCanada and Adjacent Areas: Canadian Society of Petroleum Geologists, Memoir 13, 775 p.

GinsBuRG, R.N., and JAMES, N.P., 1973, British Honduras by submarine: Geotimes, v. 18, p. 23-24.

Goyet, C., Bradshaw, A.L., and Brewer, P.G., 1991, The carbonate system in the Black Sea: Deep-Sea Research, v. 38, p. 1049-1068. 
Grey, K., and Thorne, A.M., 1985, Biostratigraphic significance of stromatolites in upward shallowing sequences of the early Proterozoic Duck Creek Dolomite, Western Australia: Precambrian Research, v. 29, p. 183-206.

Grotzinger, J.P., 1986a, Cyclicity and paleoenvironmental dynamics, Rocknest platform, northwest Canada: Geological Society of America Bulletin, v. 97, p. 1208-1231.

GrotzINGER, J.P., 1986b, Evolution of early Proterozoic passive-margin carbonate platform: Rocknest Formation, Wopmay Orogen, N.W.T., Canada: Journal Sedimentary Petrology, v. 56, p. 831847.

Grotzinger, J.P., 1988, Introduction to Precambrian reefs: in GeldSETzer, H., James, N.P. and TebbUTt, G., eds., Reefs-Canada and Adjacent Areas: Canadian Society of Petroleum Geologists, p. $9-12$.

Grotzinger, J.P., 1989, Facies and evolution of Precambrian carbonate depositional systems: emergence of the modern platform archetype: in CREvello, P.D., WILSON, J.L., SARG, J.F., and READ, J.F., eds., Controls on Carbonate Platform and Basin Development: Society of Economic Paleontologists and Mineralogists Special Publication 44, p. 79-106.

Grotzinger, J.P., 1990, Geochemical model for Proterozoic stromatolite decline: American Journal of Science, v. 290-A, p. 80103.

Grotzinger, J.P., 1994, Trends in Precambrian carbonate sediments and their implication for understanding evolution: in BENGTSON, S., ed., Early Life on Earth: Columbia University Press, New York, p. $245-258$.

Grotzinger, J.P., Beukes, N., and Sumner, D.Y., 1993, Archean carbonate sedimentation in an active extensional basin, Belingwe greenstone belt, Zimbabwe: Geological Society of America, Abstracts with Programs, v. 25, p. 64.

Grotzinger, J.P., and Friedman, J.S., 1989, Occurrence of thick crusts of former botryoidal aragonite, Rifle and Beechey Formations (1.97 Ga), Kilohigok Basin, N.W.T.: Geological Association of Canada Program with Abstracts, v. 14, p. A77.

Grotzinger, J.P., and Kasting, J.F., 1993, New constraints on Precambrian ocean composition: Journal of Geology, v. 101, p. 235243.

Grotzinger, J., and KhETANi, A., 1994, Facies and diagenesis of late Vendian thrombolite-shelly invertebrate (Cloudina?) pinnacle reefs, Nama Group, Namibia: Geological Society of America (Northeast Section), Abstracts with Programs, p. 56.

GrotzingER, J.P., and READ, J.F., 1983, Evidence for primary aragonite precipitation, lower Proterozoic (1.9 Ga) dolomite, Wopmay orogen, northwest Canada: Geology, v. 11, p. 710-713.

Grotzinger, J.P., and Sumner, D.S., in prep, Archean carbonate facies models.

Gruszczynski, M., Halas, S., Hoffman, A., and Malkowski, K., 1989, A brachiopod calcite record of the oceanic carbon and oxygen isotope shifts at the Permian/Triassic transition: Nature, v. 337, p. $64-68$.

Guo, L., and Riding, R., 1992, Microbial micritic carbonates in uppermost Permian reefs, Sichuan Basin, southern China: Some similarities with Recent travertines: Sedimentology, v. 39, p. 3753.

Hambrey, M.J., and Harland, W.B., 1985, The late Proterozoic glacial era: Palaeogeography, Palaeoclimatology, Palaeoecology, v. 51, p. 255-272.

HaQ, B.U., Hardenbol, J., and Vail, P.R., 1987, Chronology of fluctuating sea levels since the Triassic: Science, v. 235, p. 1156-1167.

Hayes, P.T., 1964, Geology of the Guadalupe Mountains, New Mexico: United States Geological Survey Professional Paper 446, 69 p.

Hegenberger, W., 1993, Stratigraphy and sedimentology of the Late Precambrian Witvlei and Nama Groups, east of Windhoek: Geological Survey of Namibia Memoir 17, $82 \mathrm{p}$.

HofFMAN, P.F., 1975, Shoaling-upward shale-to-dolomite cycles in the Rocknest Formation (lower Proterozoic), N.W. Territories,
Canada: in Ginsburg, R.N., ed., Tidal Deposits: Springer-Verlag, Berlin, p. 257-265.

HofmanN, H.J., and JACKson, G.D., 1988, Proterozoic ministromatolites with radial-fibrous fabric: Sedimentology, v. 34, p. 963-971.

Holland, H.D., 1984, The Chemical Evolution of the Atmosphere and Oceans: Princeton University Press, Princeton, $582 \mathrm{p}$.

Holland, H.D., and BeuKES, N.J., 1990, A paleoweathering profile from Griqualand West, South Africa: Evidence for a dramatic rise in atmospheric oxygen between 2.2 and 1.9 b.y.b.p.: American Journal of Science, v. 290-A, p. 1-34.

Hollingworth, N.T.J., and Tucker, M.E., 1987, The Upper Permian (Zechstein) Tunstall reef of north east England: palaeoecology and early diagenesis: in PERYT, T.M., ed., The Zechstein Facies in Europe: Springer-Verlag, Berlin, p. 23-50.

HoLSER, W.T., 1984, Gradual and abrupt shifts in ocean chemistry during Phanerozoic time: in Holland, H.D., and Trendall, A.F., eds., Patterns of Change in Earth Evolution: Springer-Verlag, Berlin, p. 123-143.

HoRoDYSKI, R.J., 1975, Stromatolites of the Lower Missoula Group (Middle Proterozoic), Belt Supergroup, Glacier National Park, Montana: Precambrian Research, v. 2, p. 215-254.

Hurst, J.M., Scholle, P.A., and Stemmerik, L., 1988, Submarine cemented bryozoan mounds, Upper Permian, Devondal, East Greenland: in Geldsetzer, H., James, N.P., and Tebbutt, G., eds., Reefs-Canada and Adjacent Areas: Canadian Society of Petroleum Geologists, p. 672-676.

IsozAKI, Y., 1994, Superanoxia across the Permo-Triassic boundary: Record in accreted deep-sea pelagic chert in Japan: Canadian Society of Petroleum Geologists, Memoir 17, p. 805-812.

KAH, L.C., and KNoll, A.H., In Press, Microbenthos in Proterozoic tidal flats: Distribution in time and space. Geology.

Kajiwara, Y., Yamakita, S., Ishida, K., Ishiga, H., and Imai, A., 1994, Development of a largely anoxic stratified ocean and its temporary massive mixing at the Permian/Triassic boundary supported by the sulfur isotopic record: Paleoclimatology, Paleogeography, Paleoecology, v. 111, p. 367-379.

KarHu, J.A., 1993, Paleoproterozoic evolution of the carbon isotope ratios of sedimentary carbonates in the Fennoscandian Shield: Geological Survey of Finland, Bulletin 371, $87 \mathrm{p}$.

KASTING, J.F., 1987, Theoretical constraints on oxygen and carbon dioxide concentrations in the Precambrian atmosphere: Precambrian Research, v. 34, p. 205-229.

KaUfman, A.J., and KNOLL, A.H., 1995, Neoproterozoic variations in the C-isotopic composition of seawater: Stratigraphic and biogeochemical implications: Precambrian Research, v. 73, p. 27-45.

Kaufman, A.J., HaYes, J.M., KNOLl, A.H., and Germs, G.J.B., 1991, Isotopic compositions of carbonates and organic carbon from upper Proterozoic successions in Namibia: Stratigraphic variation and the effects of diagenesis and metamorphism: Precambrian Research, v. 301-327.

Kaufman, A.J., Jacobsen, S.B., and KNoll, A.H., 1993, The Vendian record of $\mathrm{Sr}$ and $\mathrm{C}$ isotopic variations in seawater: Implications for tectonics and paleoclimate: Earth and Planetary Science Letters, v. 120 , p. $409-430$.

KAZMIERCZAK, J., and KEMPE, S., 1992, Recent cyanobacterial counterparts of Paleozoic Wetheredella and related problematic fossils: PALAIOS, v. 7, p. 294-304.

Kempe, S., 1990, Alkalinity: The link between anaerobic basins and shallow water carbonates?: Naturwissenschaften, v. 77, p. 426427.

KeMPE, S., and Degens, E.T., 1985, An early soda ocean?: Chemical Geology, v. 53, p. 95-108.

Kempe, S., and KAZMIERCZAK, J., 1994, The role of alkalinity in the evolution of ocean chemistry, organization of living systems, and biocalcification processes: in Doumenge, F., ed., Past and Present Biomineralization Processes: Monaco Musee Oceanographie, Bulletin 13, p. 61-116.

Kerans, C., 1982, Sedimentology and Stratigraphy of the Dismal 
Lakes Group: Unpublished Ph.D. Thesis, Carleton University, Ottawa, Canada of pages.

KING, P.B., 1942, Permian of west Texas and southeastern New Mexico: American Association of Petroleum Geologists Bulletin, v. 26, p. $535-763$

KING, P.B., 1948, Geology of the southern Guadalupe Mountains, Texas: United States Geological Survey Professional Paper 215, 215.

KiRKLAND, B.L., LoNGACRE, S.A., and SToudT, E.L., 1993, Reef: in Bebout, D.G., and Kerans, C., ed., Guide to the Permian Reef Geology Trail, McKittrick Canyon, Guadalupe Mountains National Park, West Texas: Texas Bureau of Economic Geology, Guidebook 26, p. 23-31.

KNoLL, A.H., 1992. Biological and biogeochemical preludes to the Ediacaran radiation: in LIPPS, J.H., and SIGNOR, P.W., eds., The Origin and Early Evolution of the Metazoa: Plenum Press, New York, p. 53-84.

KNOLL, A.H., FaIRCHILd, I.J., and SwetT, K., 1993b, Calcified microbes in Neoproterozoic carbonates: Implications for our understanding of the Proterozoic/Cambrian transition: PALAIOS, v. 8 p. $512-525$.

KNoll, A.H., and Grotzinger, J.P., In Prep, Stromatolites in Precambrian carbonates: Evolutionary mileposts or environmental dipsticks?: Annual Review of Earth and Planetary Sciences.

Knoll, A.H., Grotzinger, J.P., and Sergeev, V., 1993a, Carbonate precipitation in stratiform and domal structures from the Mesoproterozoic Kotuikan Formation, northern Siberia: Geological Society of America, Abstracts with Programs, v. 25, p. A357.

KNoll, A.H., Hayes, J.M., Kaufman, A.J., SWeTt, K., and LamberT, I.B., 1986, Secular variation in carbon isotope ratios from Upper Proterozoic successions of Svalbard and East Greenland: Nature, v. 321 , p. $832-838$.

KNoll, A.H., and Swetr, K., 1990, Carbonate deposition during the later Proterozoic Era: An example form Spitsbergen: American Journal of Science, v. 290-A, p. 104-132.

KNoll, A.H., and Walter, M.R., 1992, Latest Proterozoic stratigraphy and earth history: Nature, v. 356, p. 673-678.

KomaR, V.A., 1989, Classification of the microstructures of the Upper Precambrian stromatolites: Himalayan Geology, v. 13, p. 229-238.

KuMP, L.R., 1991, Interpreting carbon-isotope excursions: Strangelove oceans: Geology, v. 19, p. 299-302.

LAND, L.S., and GoREAU, T.F., 1970, Submarine lithification of Jamaican reefs: Journal of Sedimentary Petrology, v. 36, p. 457-462.

LANG, W.B., 1937, The Permian formations of the Pecos valley of New Mexico and Texas: American Association of Petroleum Geologists Bulletin, v. 21 , p. $833-898$.

LI, T.H., TakahashI, T., and Broecker, W.S., 1969, The degree of saturation of $\mathrm{CaCO}_{3}$ in the oceans: Journal of Geophysical Research, v. 74 , p. $5507-5525$

LLOYD, E.R., 1929, Capitan limestone and associated formations in New Mexico: American Association of Petroleum Geologists Bulletin, v. 13 , p. $645-658$.

MagariTz, M., and SChULze, K.H., 1980, Carbon isotope anomaly of the Permian period: Contributions of Sedimentology, v. 9, p. 269277.

Magaritz, M., and Turner, P., 1982, Carbon cycle changes of the Zechstein Sea: Isotopic transition zone in the Marl Slate: Nature, v. 297, p. 1982 .

Magaritz, M., ANDERson, R.Y., Holser, W.T., SAltzman, E.S., and GARBER, J., 1983, Isotope shifts in the Late Permian of the Delaware basin, Texas, precisely timed by varved sediments: Earth and Planetary Science Letters, v. 66, p. 111-124.

Magaritz, M., Krishnamurphy, R.V., and Holser, W.T., 1992, Parallel trends in organic and inorganic carbon isotopes across the Permian-Triassic boundary: American Journal of Science, v. 292, p. $727-739$.

Malkowski, K., Gruszczynski, M., Hoffman, A., and Stanislaw, H., 1989, Oceanic stable isotope composition and a scenario for the Permo-Triassic crisis: Historical Biology, v. 2, p. 289-309.
Mazzullo, S.J., and Cys, J.M., 1977, Submarine cements in Permian boundstones and reef-associated rocks, Guadalupe Mountains, west Texas and southeastern New Mexico: in Hileman, M.E., and Mazzullo, S.J., eds., Upper Guadalupian Facies, Permian Reef Complex, Guadalupe Mountains, New Mexico and West Texas: Field Conference Guidebook: Permian Basin Section-Society of Economic Paleontologists and Mineralogists, p. 151-200.

MorRis, R.C., and TRENDALL, A.F., 1988, A model for the deposition of the microbanded Precambrian iron-formations: American Journal of Science, v. 288, p. 664-669.

MrUK, D.H., 1989, Diagenesis of the Capitan limestone, Upper Permian, McKittrick canyon, west Texas: in HARRIs, P.M., and Grover, G.A., ed., Subsurface and Outcrop Examination of the Capitan Shelf Margin, Northern Delaware Basin; SEPM Core Workshop No. 13: Society of Economic Paleontologists and Mineralogists, p. $387-406$.

MUCCI, A., and MorSE, J.W., 1983, The incorporation of $\mathrm{Mg}^{+2}$ and $\mathrm{Sr}^{+2}$ into calcite overgrowths: Influences of growth rate and solution composition: Geochimica et Cosmochimica Acta, v. 47, p. 217-233.

Narbonne, G.M., Kaufman, A.J., and Knoll, A.H., 1994, Integrated chemostratigraphy and biostratigraphy of the Windermere Supergroup, northwestern Canada: Implications for Neoproterozoic correlations and the evolution of animals: Geological Society of America Bulletin, v. 106, p. 1281-1292.

Newell, N.D., 1955, Depositional fabric in Permian reef limestones: Journal of Geology, v. 63, p. 301-309.

Newell, N.D., RigBy, J.K., Fischer, A.G., Whiteman, A.J., Hickcox, J.E., and BRAdLEY, J.S., 1953, The Permian Reef Complex of the Guadalupe Mountains Region, Texas and New Mexico: San Francisco, W.H. Freeman, 236 p.

Peryt, T.M., 1978, Sedimentology and paleoecology of the Zechstein Limestone (Upper Permian) in the Fore-Sudetic area (western Poland): Sedimentary Geology, v. 20, p. 217-243.

Peryt, T.M., 1986, Zechstein Stromaria (= Archaeolithoporella)-cement reefs in Thuringa: Neues Jahrbuch Geologie und Paläontologie, v. 5 , p. 307-316.

Pisera, A., and Zawidzka, K., 1981, Archaeolithporella from the Upper Permian reef limestones of the northern Caucasus: Bulletin de l'Academie Polonaise des Sciences, Series des sciences de la Terre, V. 29, p. 233-238.

RoscoE, S.M., 1969, Huronian rocks and uraniferous conglomerates in the Canadian Shield: Geological Survey of Canada Paper 68$40,208 \mathrm{p}$.

Sami, T., and James, N.P., In Press, Synsedimentary cements as platform building blocks, Paleoproterozoic Pethei Group, northwestern Canada: Journal of Sedimentary Research.

SCHERMERHORN, L.J.G., 1974, Late Precambrian mixtites: Glacial and/ or nonglacial?: American Journal of Science, v. 274, p. 673-824.

ScHMIDT, V., 1977, Inorganic and organic growth and subsequent diagenesis in the Permian Capitan reef complex, Guadalupe Mountains, New Mexico: in Hileman, M.E., and Mazzullo, S.J., eds., Upper Guadalupian Facies, Permian Reef Complex, Guadalupe Mountains, New Mexico and West Texas: Field Conference Guidebook 77-16: Permian Basin Section-Society of Economic Paleontologists and Mineralogists, p. 93-132.

Schmidt, V., and KLEMENT, K.W., 1971, Early diagenetic origin of reef framework in the Permian Capitan reef complex, Guadalupe Mountains, Texas and New Mexico (abst.): VIII International Sedimentological Congress Program with Abstracts, Heidelberg, p. 89.

SCHOLLE, P.A., 1995, Carbon and sulfur isotope stratigraphy of the Permian and adjacent intervals: in PERYT, T.M., and ULMER-SCHOLLE, D.S., eds., The Permian of Northern Pangea, Volume 1: Paleogeography, Paleoclimates, Stratigraphy: SpringerVerlag, New York, p. 133-149.

SEDGWICK, A., 1829, On the geological relations and internal structure of the Magnesian Limestone: Transactions of the Geological Society of London, v. 2, p. 37-124. 
Semikhatov, M.A., and RaABen, M.E., 1993, Dynamics of the taxonomic diversity of Riphean and Vendian stromatolites in northern Eurasia: Stratigraphy and Geological Correlation, v. 1, p. 133141.

Sergeev, V.N., Knoll, A.H., and Grotzinger, J.P., 1995, Paleobiology of the Mesoproterozoic Billyakh Group, Anabar Uplift, northern Siberia: Journal of Paleontology, Supplement to No. 1, v. 69, p. $1-37$.

Simo, J.A.T., ScotT, R.W., and MASSE, J-P., 1993, Cretaceous carbonate platforms: American Association of Petroleum Geologists Memoir 56, $479 \mathrm{p}$.

SINGH, U,, 1987, Ooids and cements from the late Precambrian of the Flinders Ranges, South Australia: Journal of Sedimentary Petrology, v. 57 , p. $117-127$.

Smith, D.B., 1980, The evolution of the English Zechstein basin: Contributions to Sedimentology, v. 9, p. 7-34.

Sмiтн, D.S., 1981, The Magnesian Limestone (Upper Permian) reef complex of northeastern England: in ToomEy, D.F., ed., European Fossil Reef Models: Society of Economic Paleontologists and Mineralogists Special Publication 30, p. 161-186.

SмIтH, D.S., 1994, The geology of the country around Sunderland: Memoir of the British Geological Survey, Sheet 21.

SMITH, D.S., 1995, Marine Permian of England: Chapman and Hall, London, $224 \mathrm{p}$.

Sumner, D.Y., 1995, Facies, Paleogeography, and Carbonate Precipitation on the Archean (2520 Ma) Campbellrand-Malmani Carbonate Platform, Transvaal Supergroup, South Africa. Ph.D. Dissertation, Massachusetts Institute of Technology, Cambridge, $516 \mathrm{p}$.

SumNER, D.Y., and GRotzinger, J.P., in press a, Herringbone calcite: Journal of Sedimentary Research.

Sumner, D. Y., and Grotzinger, J. P., in press b, Were Archean calcium carbonate precipitation kinetics related to oxygen concentration?: Geology.

ToOMEY, D.F., and CYs, J.M., 1977, Rock/biotic relationships of the Permian Tansill-Capitan facies exposed on the north side of the entrance to Dark Canyon, Guadalupe Mountains, southeastern New Mexico: in Hileman, M.E., and Mazzullo, S.J., eds., Upper Guadalupian Facies, Permian Reef Complex, Guadalupe Mountains, New Mexico and West Texas: Field Conference Guidebook 77-16: Permian Basin Section--Society of Economic Paleontologists and Mineralogists, p. 133-150.

TUCKER, M.E., 1986, Formerly aragonitic limestones associated with tillites in the late Proterozoic of Death Valley, California: Journal of Sedimentary Petrology, v. 56, p. 818-830.

Tucker, M.E., and Hollingworth, N.T.J., 1986, The Upper Perm- ian reef complex (EZ1) of northeast England: diagenesis in a marine to evaporitic setting: in SCHROEDER, J.H., and PuRSER, B.H., ed., Reef Diagenesis: Springer-Verlag, p. 270-290.

TuRner, E.C., NARBonNe, G.M., and JAMES, N.P., 1993, Neoproterozoic reef microstructures from the Little Dal Group, northwestern Canada: Geology, v. 3, p. 259-262.

TYrell, W.W., JR., 1964, Petrology and stratigraphy of near reef Tansill-Lamar strata, Guadalupe Mountains, Texas and New Mexico: Roswell Geological Society Guidebook, p. 66-75.

VaIL, P.R., Mitchum, R.M., and Thompson, S., III, 1977, Seismic stratigraphy and global changes of sea level, Part 3: Relative changes of sea level from coastal onlap: in Payton, C., ed., Seismic Stratigraphy-Applications to Hydrocarbon Exploration: American Association of Petroleum Geologists, Memoir 26, p. 63-81.

WALTER, M.R., and Bauld, J., 1983, The association of sulphate evaporites, stromatolitic carbonates and glacial sediments: Examples from the Proterozoic of Australia and the Cainozoic of Antarctica: Precambrian Research, v. 21, p. 129-148.

Wignall, P.B., and Hallam, A., 1992, Anoxia as a cause of the Permian/Triassic mass extinction: Facies evidence from northern Italy and the western United States: Paleogeography, Paleoclimatology, and Paleoecology, v. 93, p. 21-46.

Wilkinson, B.H., OWEN, R.M., and Carroll, A.R., 1985, Submarine hydrothernal weathering, global eustasy, and carbonate polymorphism in Phanerozoic marine oolites: Journal of Sedimentary Petrology, v. 55, p. 171-183.

Wood, R., Dickson, J.A.D., and KirkLAND-George, B., 1994, Turning the Capitan reef, upside down: A new appraisal of the ecology of the Permian Capitan reef, Guadalupe mountains, Texas and New Mexico: Palaios, v. 9, p. 422-427.

WraY, J.L., 1977, Calcareous Algae: Amsterdam, Elsevier, 76-77.

YouNG, G.M., 1976, Iron-formation and glaciogenic rocks of the Rapitan Group, Northwest Territories, Canada: Precambrian Research, v. 3, p. 137-158.

YuREwICz, D.A., 1977, Origin of the massive Capitan Limestone (Permian), Guadalupe Mountains, New Mexico and West Texas, in. Upper Guadalupian Facies, Permian Reef Complex, Guadalupe Mountains, New Mexico and West Texas: in Hileman, M.E., and Mazzullo, S.J., eds., Upper Guadalupian Facies, Permian Reef Complex, Guadalupe Mountains, New Mexico and West Texas: Field Conference Guidebook: Permian Basin Section-Society of Economic Paleontologists and Mineralogists, p. 45-92.

ZaChOS, J.C., and ARThUR, M.A., 1986, Paleoceanography of the Cretaceous/Tertiary boundary event: Inferences from stable isotopic and other data: Paleoceanography, v. 1, p. 5-26. 